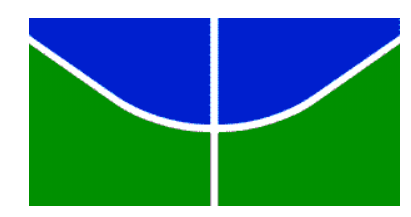

UNIVERSIDADE DE BRASÍLIA

FACULDADE DE AGRONOMIA E MEDICINA VETERINÁRIA

DESEMPENHO E MEDIDAS BIOMÉTRICAS DE CORDEIROS DE DIFERENTES GRUPOS GENÉTICOS TERMINADOS EM CONFINAMENTO

ANNE CAROLINE OLIVEIRA BARBOSA

DISSERTAÇÃO DE MESTRADO EM CIÊNCIAS ANIMAIS 


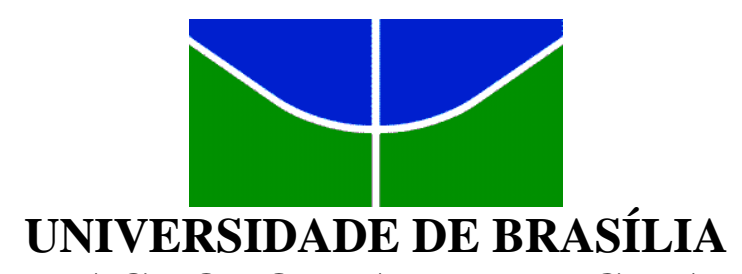

FACULDADE DE AGRONOMIA E MEDICINA VETERINÁRIA

DESEMPENHO E MEDIDAS BIOMÉTRICAS DE CORDEIROS DE DIFERENTES GRUPOS GENÉTICOS TERMINADOS EM CONFINAMENTO

ANNE CAROLINE OLIVEIRA BARBOSA

ORIENTADOR: CLAYTON QUIRINO MENDES

DISSERTAÇÃO DE MESTRADO EM CIÊNCIAS ANIMAIS

PUBLICAÇÃO: 171/2016

BRASÍLIA/DF

OUTUBRO DE 2016 


\section{UNIVERSIDADE DE BRASÍLIA \\ FACULDADE DE AGRONOMIA E MEDICINA VETERINÁRIA}

DESEMPENHO E MEDIDAS BIOMÉTRICAS DE CORDEIROS DE DIFERENTES GRUPOS GENÉTICOS TERMINADOS EM CONFINAMENTO

ANNE CAROLINE OLIVEIRA BARBOSA

DISSERTAÇ̃̃O DE MESTRADO SUBMETIDA AO PROGRAMA DE PÓS-GRADUACAÇÃO EM CIÊNCIAS ANIMAIS DA FACULDADE DE AGRONOMIA E MEDICINA VETERINÁRIA DA UNIVERSIDADE DE BRASÍLIA, COMO PARTE DOS REQUISITOS PARA OBTENÇÃO DE GRAU DE MESTRE EM CIÊNCIAS ANIMAIS.

APROVADA POR:

CLAYTON QUIRINO MENDES

(Orientador)

IVO PIVATO

(Examinador Interno)

DANIELA OLIVEIRA BRANDÃO

(Examinador Externo)

BRASíLIA/DF, 13 de outubro de 2016. 


\section{REFERÊNCIA BIBLIOGRÁFICA E CATALOGAÇÃO}

BARBOSA, A. C. O. Desempenho e medidas biométricas de cordeiros de diferentes grupos genéticos terminados em confinamento Brasília: Faculdade de Agronomia e Medicina Veterinária, Universidade de Brasília, 2016, 51 p. Dissertação de Mestrado.

Documento formal, autorizando reprodução desta dissertação de mestrado para empréstimo ou comercialização, exclusivamente para fins acadêmicos, foi passado pelo autor à Universidade de Brasília e acha-se arquivado na Secretaria do Programa. O autor e seu orientador reservam para si os outros direitos autorais de publicação. Nenhuma parte desta dissertação de mestrado pode ser reproduzida sem a autorização por escrito do autor e do seu orientador. Citações são estimuladas, desde que citada à fonte.

\section{FICHA CATALOGRÁFICA}

Ficha catalográfica elaborada automaticamente, com os dados fornecidos pelo(a) autor(a)

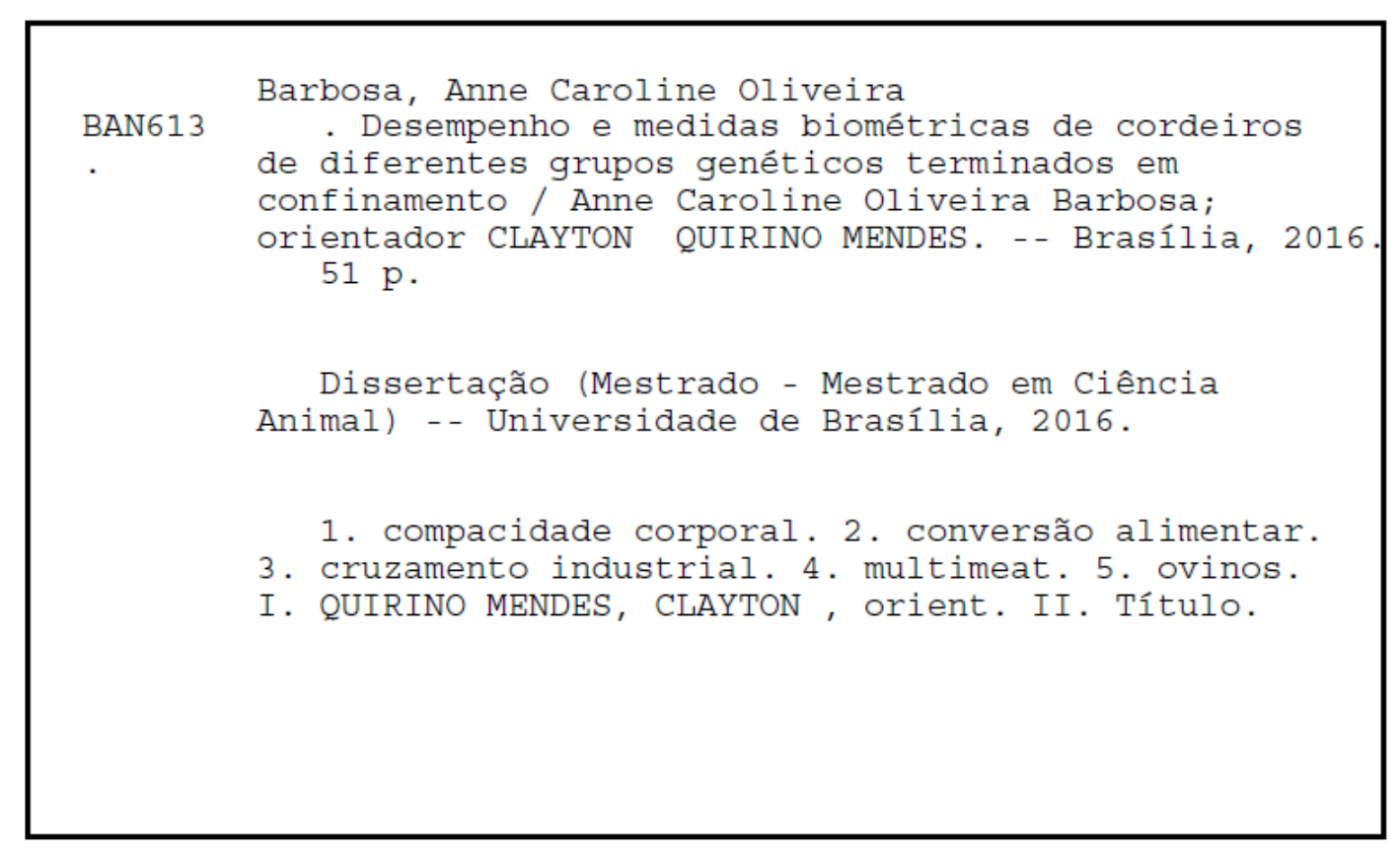




\section{AGRADECIMENTOS}

Agradeço a todos que contribuíram para essa conquista em minha vida, em especial aos meus pais por toda dedicação, por me darem força nos momentos mais difíceis e por acreditarem no meu potencial.

Aos meus grandes amigos da vida, sempre presentes nos momentos bons e ruins, por todo companheirismo e amizade.

Ao meu orientador, professor Clayton Quirino Mendes, por todo apoio ao longo dessa importante etapa da minha vida.

Ao professor Rodrigo Vidal, que me acompanha desde a graduação, agradeço por todo aprendizado e paciência.

A toda equipe do centro de manejo de ovinos por tornar esse experimento possível.

A Deus pela existência.

Agradeço com muita emoção a todos que tornaram esse sonho possível.

"Não é o mais forte que sobrevive, nem o mais inteligente, mas o que melhor se adapta às mudanças". Charles Darwin 


\section{ÍNDICE}

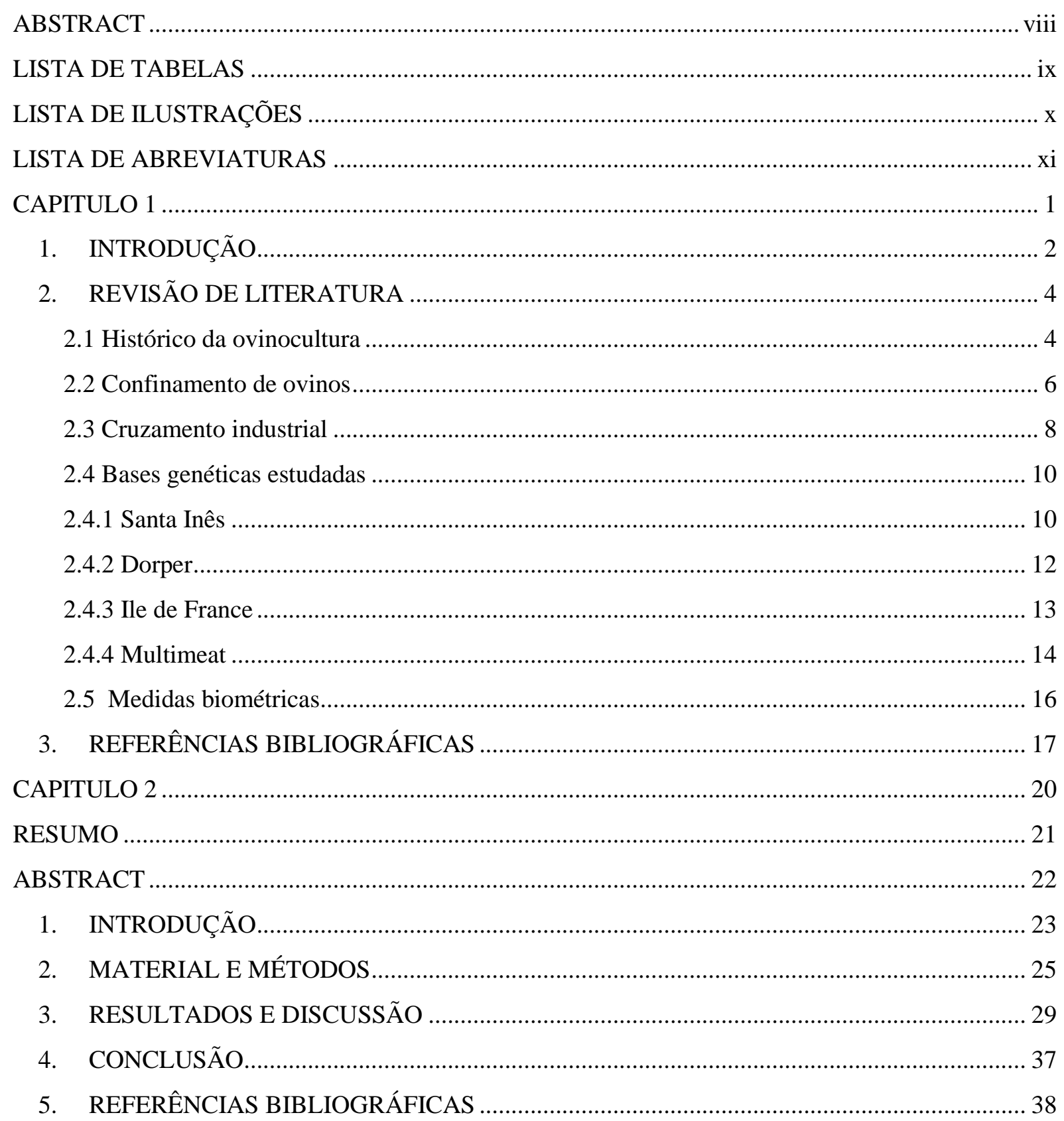




\title{
RESUMO \\ DESEMPENHO E MEDIDAS BIOMÉTRICAS DE CORDEIROS DE DIFERENTES GRUPOS GENÉTICOS TERMINADOS EM CONFINAMENTO
}

\author{
Anne Caroline Oliveira Barbosa, Clayton Quirino Mendes ${ }^{1}$ \\ ${ }^{1}$ Faculdade de Agronomia e Medicina Veterinária da Universidade de Brasília, Brasília/DF.
}

Objetivou-se com esse estudo avaliar o desempenho e as medidas biométricas "in vivo" de cordeiros de três diferentes grupos genéticos mantidos em sistema de confinamento. Foram utilizados 24 cordeiros machos e não castrados, formando três tratamentos: 1) $1 / 2$ Santa Inês x $1 / 2$ Dorper, 2) $1 / 2$ Santa Inês x $1 / 2$ Ile de France e 3) tricross (1/4 Santa Inês $+1 / 4$ Dorper $+1 / 2$ Multimeat), com peso corporal inicial em torno de $20 \mathrm{~kg}$ e idade média de 70 dias, distribuídos em um delineamento inteiramente casualizado. O experimento teve duração de 76 dias, sendo 10 dias de adaptação dos animais ao manejo e 66 dias de período experimental. A relação volumoso concentrado foi de 30:70. Ao término do período experimental, os animais foram pesados para obtenção do peso final e realização das seguintes medidas biométricas: comprimento corporal; altura do anterior; altura do posterior; perímetro torácico; largura da garupa; largura do tórax. O índice de compacidade corporal foi calculado a partir da relação peso final/comprimento corporal. Os animais do grupo genético $1 / 2$ Santa Inês x 1/2 Dorper apresentaram peso final superior aos animais tricross, enquanto que nos animais $1 / 2$ Santa Inês x $1 / 2$ Ile de France o peso final não diferiu dos demais. As variáveis ganho de peso médio diário, ganho de peso total, consumo de matéria seca, conversão alimentar e eficiência alimentar não foram influenciadas pelos grupos genéticos. Nos resultados referentes às medidas biométricas "in vivo" os valores encontrados foram semelhantes entre os grupos genéticos avaliados. Somente na variável altura de anterior houve diferença $(\mathrm{P}<0,05)$, sendo que os animais do tratamento $1 / 2$ Santa Inês x $1 / 2$ Dorper apresentaram valores superiores ao dos animais tricross. O cruzamento industrial utilizando ovelhas Santa Inês como base materna é eficaz para produção de cordeiros em sistema de confinamento, proporcionando animais precoces e com medidas biométricas desejáveis para composição de carcaça. A utilização da raça Multimeat para produção de cordeiros em sistema de confinamento gera resultados satisfatórios e semelhantes aos apresentados por cordeiros oriundos das raças de aptidão para carne avaliadas nesse estudo.

Palavres-chave: compacidade corporal, conversão alimentar, cruzamento industrial, ganho de peso, multimeat, ovinos. 


\title{
ABSTRACT \\ PERFORMANCE AND BIOMETRIC CHARACTERISTICS OF FEDLOT LAMBS FROM DIFFERENT GENETIC GROUPS
}

\author{
Anne Caroline Oliveira Barbosa, Clayton Quirino Mendes ${ }^{1}$ \\ ${ }^{1}$ School of Agronomy and Veterinary Medicine - University of Brasilia, DF
}

The objective of this study was to evaluate the performance and biometric measures "in vivo" of lambs of three different genetic groups feedlot system. 24 lambs were used and not castrated, forming three treatments: 1) $1 / 2$ Santa Inês x $1 / 2$ Dorper, 2) $1 / 2$ Santa Inês x $1 / 2$ Ile de France and 3) tricross ( $1 / 4$ Santa Inês $+1 / 4$ Dorper $+1 / 2$ Multimeat), with initial body weight around $20 \mathrm{~kg}$ and average age of 70 days, distributed in a completely randomized design. The experiment lasted 76 days, 10 days of adaptation of animals to management and 66-day trial. The concentrate roughage was 30:70. At the end of the experimental period, the animals were weighed to obtain the final weight and achievement of the following biometric measurements body length; height above; the later time; Girth; width of the croup; width of the thorax. Body compactness index was calculated from the relationship final / body length weight. The genetic groups $1 / 2$ Santa Inês x $1 / 2$ Dorper showed higher final weight than tricross animals, whereas in $1 / 2$ Santa Inês $x 1 / 2$ Ile de France animals final weight did not differ from the others. The variables average daily gain, total weight gain, dry matter intake, feed conversion and feed efficiency were not affected by genetic groups. The results of the biometric measures "in vivo" the values were similar among genetic groups evaluated. Only the previous variable height difference $(\mathrm{P}<0.05)$, animals $1 / 2$ Santa Inês $x 1 / 2$ Dorper showed higher values. The crossbreeding using Santa Inês sheep as a maternal base is effective for the production of feedlot lambs, providing early animals with biometric measurements desirable for carcass composition. The use of the Multimeat breed for lamb production in a feedlot system is recommended once lamb performance is similar to those presented by lambs from the breeds of meat fitness evaluated in this study.

keywords: body compactness, feed, industrial crossing, weight gain, multimeat, sheep. 
LISTA DE TABELAS

Tabela 1 - Média dos valores de PI, PF, GF, GMPD, CMS, CA e EA...................................29

Tabela 2 - Avaliações biométricas "in vivo": CEsp, CNeoz, LG, LT, C. perna, Alt. anterior,

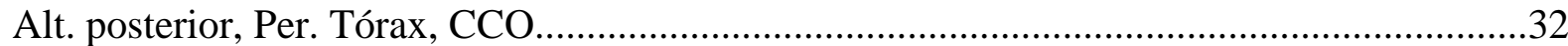




\section{LISTA DE ILUSTRAÇÕES}

Figura 1.1: Evolução do rebanho ovino no Brasil................................................................4

Figura 1.2: Rebanho ovino no Brasil por regiões...........................................................

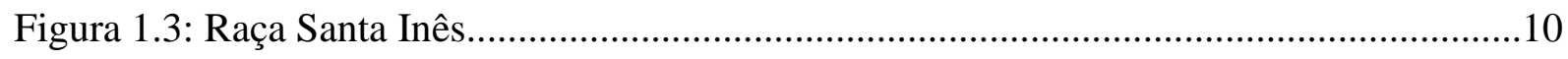

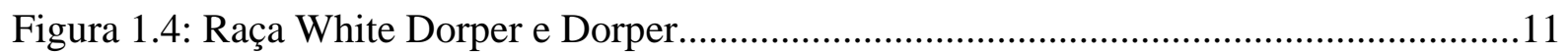

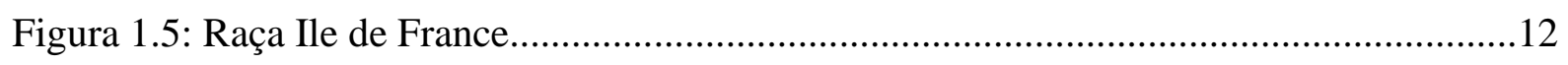

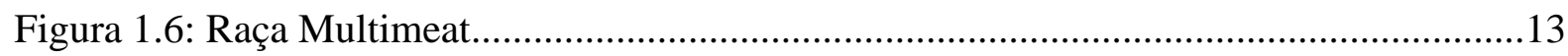

Figura 1.7: Transferência vertical do gene Booroola........................................................ 14

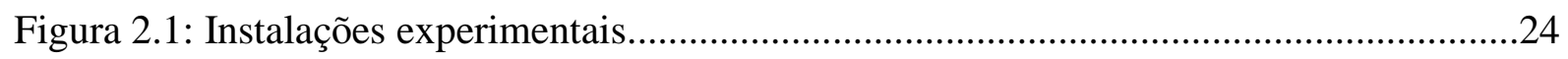

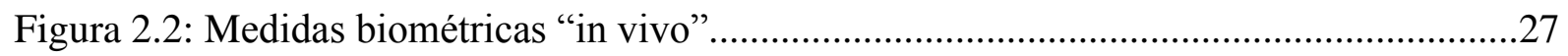




\section{LISTA DE ABREVIATURAS}

$\begin{array}{ll}\text { CA } & \text { Conversão Alimentar } \\ \text { CMS } & \text { Consumo de Matéria Seca } \\ \text { CV } & \text { Coeficiente de variação } \\ \text { DIC } & \text { Delineamento Inteiramente Casualizado } \\ \text { DO } & \text { Dorper } \\ \text { EA } & \text { Eficiência Alimentar } \\ \text { g/dia } & \text { Gramas por Dia } \\ \text { GMD } & \text { Ganho Médio Diário } \\ \text { GPT } & \text { Ganho de peso toal } \\ \text { ILE } & \text { Ile de France } \\ \text { kg/dia } & \text { Quilogramas por Dia } \\ \text { MM } & \text { Multimeat } \\ \text { MS } & \text { Matéria Seca } \\ \text { PF } & \text { Peso final } \\ \text { PI } & \text { Peso inicial } \\ \text { SI } & \text { Santa Inês } \\ \text { h } & \text { horas }\end{array}$


CAPITULO 1 


\section{INTRODUÇÃO}

Pesquisas sobre ovinocultura vêm crescendo no Brasil devido ao alto potencial produtivo desses animais e o crescente mercado consumidor e comprovam que a intensificação da produção promove aumento dos índices produtivos existentes, além de garantir um produto de alta qualidade para o consumidor. A produção de carne ovina é, geralmente, uma atividade alternativa cuja renda complementa os negócios, sendo que o cordeiro (animal jovem) é a categoria animal que fornece carne de melhor qualidade, além de apresentar os maiores rendimentos de carcaça e maior eficiência de produção, devido a sua alta velocidade de crescimento (Pires et al., 2000).

Dentre alternativas eficazes para terminação, a utilização intensiva de pastagens e o confinamento tem despertado grande interesse entre os ovinocultores. (Yamamoto et al., 2007)). Além disso, o mercado consumidor tem apresentado maior aceitabilidade à carne de cordeiro que não possui sabor tão característico como o do carneiro (Ferrão et al., 2009).

De acordo com Dias (2014), os produtores brasileiros necessitam melhorar sua eficiência produtiva assegurando a qualidade da carne, já que o consumidor está cada vez mais exigente. Existem diversos fatores que influenciam a qualidade da carne, entre eles: raça, genética, nutrição, sistema de criação, forma de abate e outros. O autor ressaltou ainda que a nutrição animal é de grande importância, pois afeta direta e indiretamente a qualidade da carne. Indiretamente pelo efeito da idade ao abate e diretamente pela ingestão de substâncias que alteram, por exemplo, a composição química e as características quantitativas da carcaça, interferindo principalmente na proporção do tecido adiposo em relação ao muscular.

Pires et al. (2000) relataram que cordeiros apresentam maiores rendimentos de carcaça e maior eficiência de produção se comparados a outras espécies, devido a sua alta 
velocidade de crescimento. Ressalta-se que entre as alternativas eficazes para terminação, o confinamento tem sido a opção de interesse dos ovinocultores.

Quando se fala sobre produção de carne é importante avaliar as características quantitativas e qualitativas da carcaça, pois elas estão diretamente relacionadas com o produto final que será oferecido ao consumidor. Quando se pensa na melhoria da produção, deve-se atentar ao potencial produtivo do animal. Para elevar produção e produtividade é necessário conhecer bem o animal e seu potencial na produção de carne. A espécie ovina apresenta uma grande vantagem quando comparada a outras: sua eficiência para ganho de peso. Com o manejo adequado o produtor consegue os resultados desejados em pouco tempo, o que é o ideal para a produção e permite uma expansão do consumo dessa carne (Alves et al., 2003).

Para poder explorar ao máximo as boas perspectivas de uma criação de cordeiros voltada para produção de carne é necessário buscar uma boa relação entre custos e retorno. Para utilizar sistemas modernos devem-se buscar animais com genética superior (Rosanova et al., 2005). Adicionalmente, Moreno et al. (2010) mencionaram que a demanda dos consumidores por produtos de maior qualidade impulsionou a procura por uma melhoria na eficiência da produção. A busca por carcaças padronizadas e oferta regular ainda são os maiores desafios.

Uma importante ferramenta utilizada para saber o melhor momento do abate dos animais é a avaliação da condição corporal do animal vivo. Por meio desta técnica é possível estimar a quantidade de músculo e tecido adiposo em relação à proporção óssea. Estudos envolvendo medidas biométricas "in vivo" e na carcaça demonstraram que estas, em conjunto, constituem bons parâmetros na avaliação para abate dos animais (Pinheiro et al., 2007).

A pesquisa acerca de novas raças introduzidas é de fundamental importância para que o produtor acompanhe os avanços tecnológicos e exigências do mercado consumidor. Recentes estudos com a raça Multimeat demonstraram que apesar de não ter sido selecionada para produção de carne, se coloca como opção para o produtor brasileiro por ser uma raça prolífera que possibilita o aumento do o rebanho a longo prazo sem comprometer a quantidade de carne produzida.

O presente estudo objetivou avaliar o desempenho produtivo e as medidas biométricas "in vivo" de cordeiros de três grupos genéticos: $1 / 2$ Santa Inês x 1/2Dorper, $1 / 2$ Santa Inês x $1 / 2$ Ile de France e "tricross" ( $1 / 4$ Santa Inês $+1 / 4$ Dorper $+1 / 2$ Multimeat) mantidos em sistema de confinamento. 


\section{REVISÃO DE LITERATURA}

\subsection{Histórico da ovinocultura}

A espécie ovina foi uma das primeiras exploradas pelo homem, tendo grande importância social e econômica, desde os primórdios da civilização. Nos dias atuais, a ovinocultura está disseminada por todo mundo como alternativa aos produtores rurais em diferentes sistemas de criação, desde o mais rústico até o mais tecnológico, com destaque para países em desenvolvimento (Rosanova et al., 2005).

De acordo com dados do IBGE, o rebanho ovino do Brasil no ano de 2014 era composto por 17.614.454 cabeças (Figura 1.1) estando 57,5\% desse total distribuído na região Nordeste, 29,3\% na região Sul e 5,57\% na região Centro-Oeste (Figura 1.2).

Apesar da redução no rebanho entre 2011 e 2012, o consumo de produtos oriundos da ovinocultura tende a aumentar nos próximos 10 anos, tanto pelo crescimento natural da população e da renda como pela organização da produção para expansão de mercado (Embrapa, 2016). 


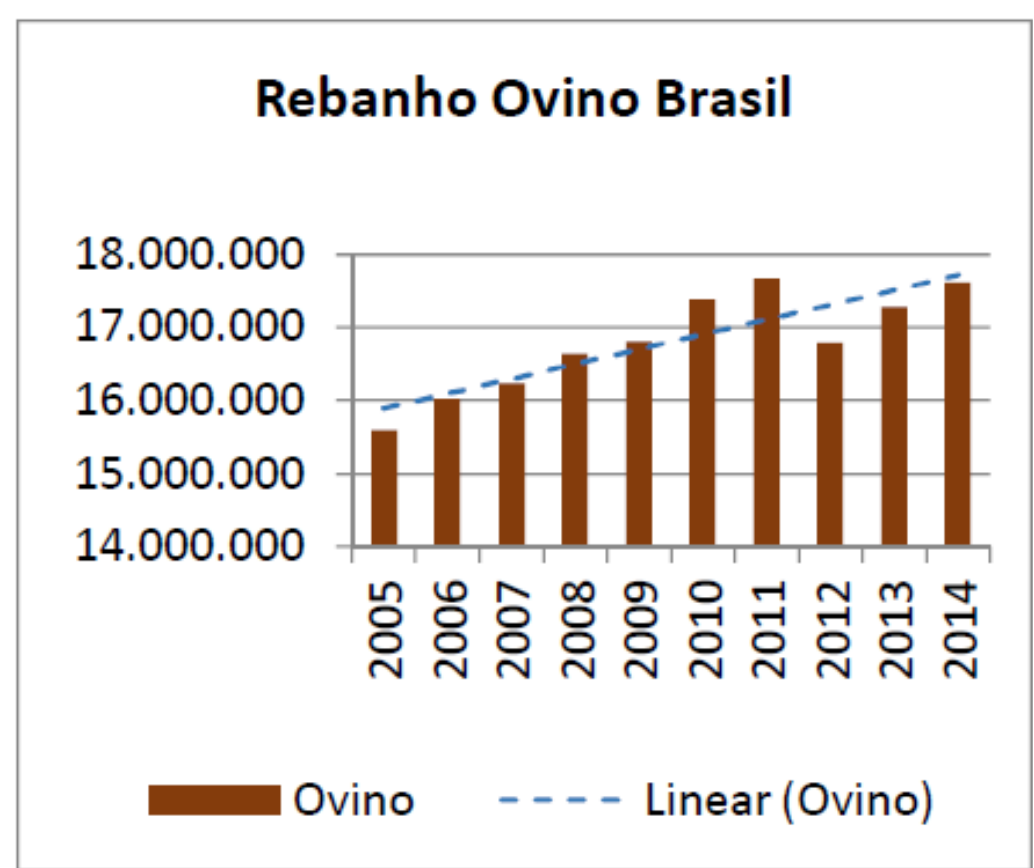

Figura 1.1: Evolução do rebanho ovino no Brasil Fonte: IBGE

No Brasil, a maior concentração de rebanhos ovinos está no estado do Rio Grande do Sul, com raças de carne, lã e mistas, e no Nordeste, com raças deslanadas de alta rusticidade. A região Sul tem perdido representatividade com o passar dos anos, sendo um dos fatores a queda no mercado de lã devido à substituição por produtos sintéticos e pela necessidade de mudar o foco do rebanho para produção de carne. (SENAR, 2014)

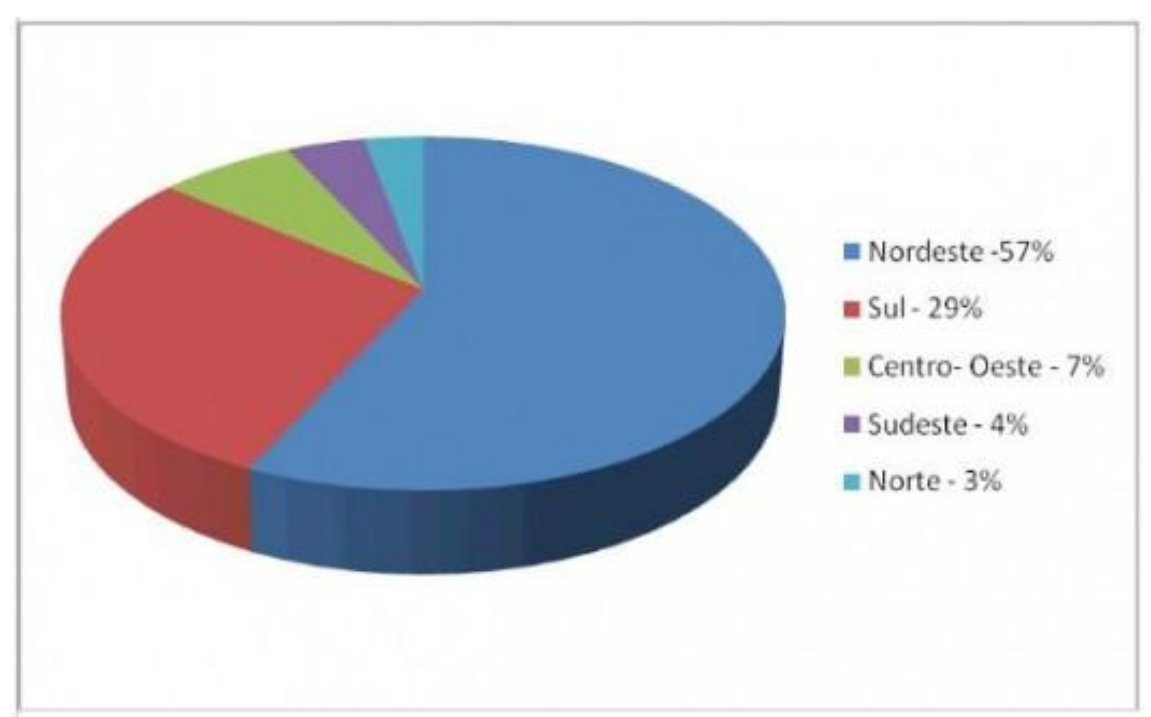

Figura 1.2: Rebanho ovino no Brasil por regiões Fonte: IBGE 
Os estados de São Paulo, Paraná e a região Centro-Oeste apresentaram crescimento significativo com potencial para produção de carne. Importante ressaltar que apesar do crescimento nos últimos anos, o Brasil importa carne ovina para abastecer o mercado consumidor, pois a oferta interna com qualidade e organização é insuficiente (Viana, 2008).

A criação de ovinos na região Centro-Sul tem crescido nos últimos anos e é voltada para o sistema intensivo de criação, uma vez que o confinamento de cordeiros, contendo dietas de elevada concentração energética, é uma excelente opção de terminação dos animais por diminuir o tempo necessário para atingirem o peso de abate e também reduzir problemas sanitários (Bueno et al., 2000).

Para conquista de mercado é sempre importante atentar para oferta de produtos com alta qualidade higiênico-sanitária e organoléptica, tendo em vista que a carne ovina está apresentando crescente consumo. Dentre os principais mercados se encontra o estado de São Paulo, que também tem sido pólo de desenvolvimento da ovinocultura no Brasil, com sistema intensivo de criação e cruzamento de raças específicas para melhoramento genético (Allen, 1991). O autor também citou que o atual mercado exige cada vez mais e o consumo de cordeiros tende a crescer, por ser uma carne considerada saudável.

A ovinocultura é de grande importância econômica na região nordeste do Brasil, porém pouco desenvolvida devido ao escasso manejo sanitário e nutricional. Isso causa altas taxas de mortalidade e peso ao abate tardio. A produção e o comércio ainda são muito desorganizados no Brasil, o que dificulta um avanço na produção por falta de conhecimento dos produtores de que uma carne de melhor qualidade terá maior aceitabilidade de mercado (Alves et al., 2003). O consumo de carne ovina nos últimos anos dentro do Brasil é crescente, principalmente a proveniente de animais jovens, pois tem maior palatabilidade (Cunha et al. 2000).

\subsection{Confinamento de ovinos}

O consumo de carne ovina ainda é menor se comparado às demais carnes. Para aumentar a competitividade e aceitabilidade existem diversos pontos que precisam ser trabalhados, como por exemplo: raça/grupo genético, tipo de alimentação, sistema de criação, 
idade ao abate, condições de armazenamento da carcaça e da carne, dentre outros. Diante desse contexto, o confinamento é uma excelente estratégia para atender aos pontos-chave da cadeia produtiva, do produtor e do consumidor, pois além de aumentar a produção, melhora a qualidade nutricional da carne por possibilitar o abate de animais mais jovens (Costa, 2011).

Pires et al. (2000) citaram que o sistema de confinamento é uma das estratégias utilizadas para melhorar o desempenho dos rebanhos de pequenos ruminantes; no entanto, deve-se sempre considerar a possibilidade de inclusão de fontes alimentares alternativas para quantificar a resposta animal em termos produtivos e econômicos. Esses autores também descreveram que o crescente mercado consumidor aliado ao alto potencial produtivo dos cordeiros são fatores que propiciam a realização de pesquisas com ovinos no Brasil. Alguns estudos já realizados comprovam que uma intensificação na produção aumenta os índices produtivos e origina um produto de melhor qualidade. Os autores ressaltaram que o cordeiro não é capaz de sustentar elevado ganho de peso pós-desmame até o abate, por isso a necessidade de métodos alternativos, como o confinamento, para melhorar o desempenho desses animais.

Alves et al. (2003) citaram que o confinamento permite ao produtor disponibilizar para o mercado consumidor animais mais jovens e com melhores características de carcaça e qualidade de carne, possibilitando o aumento do mercado de consumo. Segundo Lopes \& Magalhães (2005), o sistema de terminação em confinamento possui alto custo com alimentação e infraestrutura, havendo assim a necessidade de utilizar dieta de baixo custo, que proporcione alto ganho de peso médio diário e boa conversão alimentar, de forma a reduzir o período de permanência dos animais no confinamento e aumentar a margem de lucro.

Yamamoto et al. (2007) relataram em seu estudo que as carcaças com características ideais para o consumidor são de animais jovens, com idade inferior a 150 dias e peso corporal entre 28 e 30kg. Para chegar a esses resultados é necessário um sistema de criação intensivo com terminação em confinamento. Marques et al. (2008) citaram em seu estudo que ovinos são abatidos com peso aproximado de $30 \mathrm{~kg}$ por acreditar que com esse peso se consigam carcaças com maior concentração muscular e níveis satisfatórios de gordura. Atualmente, os frigoríficos têm preferido animais jovens ( 5 a 6 meses de idade) com peso vivo final em torno de 35 a $40 \mathrm{~kg}$, sendo que para alcançar esses resultados é necessário um sistema de criação intensivo e com terminação em confinamento 
Sousa et al. (2008) mencionaram em seu estudo que a baixa produtividade na região Nordeste está relacionada ao sistema extensivo de criação. Por isso a necessidade de se implementar o sistema de confinamento a fim de se obter maior desempenho desses animais.

Paim et al. (2010) mencionam a ovinocultura de ciclo curto como geradora de maior retorno econômico e produção de carne de melhor qualidade, especificando o confinamento como alternativa para alcançar esses resultados. Os autores relatam que o confinamento traz vantagens como: menor taxa de mortalidade, ganho de peso mais rápido, menor infestação por parasitas, redução do tempo de abate, aumento da produtividade e carcaças de melhor qualidade e acabamento. Ressaltam, porém, que esse sistema necessita de investimento para instalações, manejo intensivo e maior custo de produção que está diretamente relacionado ao tempo que esses animais permanecem no confinamento, por isso o tempo ideal para o maior lucro seria de 70 dias de confinamento.

\subsection{Cruzamento industrial}

O cruzamento industrial é uma estratégia de melhoramento genético bastante

utilizada. É possível acasalar animais de grupos genéticos diferentes de forma complementar para selecionar as melhores características de cada raça. Um dos objetivos mais almejados como cruzamento é obter o vigor híbrido, ou heterose, que é a superioridade produtiva da progênie em relação à média dos pais (Sousa et al., 2003).

Barbosa Neto et al. (2010) citaram que uma alternativa eficaz para aumentar a produção ovina através do melhoramento genético seria com o aproveitamento do potencial de raças especializadas associado a estratégias de cruzamento industrial acompanhado de seleção.

Quando se utiliza cruzamento industrial como ferramenta para aumentar a produção é importante também atentar para um melhoramento das condições nutricionais e sanitárias para que esses animais consigam expressar todo seu potencial genético (Costa et al., 2012). O produto final varia de acordo com estratégias alimentares, genéticas e de gênero, tendo em vista os anseios do mercado consumidor. Por isso é importante avaliar precisamente como fatores interferentes podem elucidar antigas duvidas, direcionar e modificar pesquisas para o produto final atual (Oliveira et al., 2013). 
O principal interesse da indústria é fornecer parâmetros de qualidade de acordo com o que o consumidor, cada vez mais exigente, deseja. Nesse contexto entra peso ao abate, gordura, conformação, entre outros. Devido a esse mercado, é necessário estabelecer sistemas de classificação de forma a aprimorar a qualidade da produção. O cruzamento é utilizado, por exemplo, para se conseguir melhor conformação de carcaça, usando raças próprias para produção de carne. Algumas formas de aprimorar o cruzamento industrial são por meio de seleção genética, introdução de raças especializadas e alimentação (Allen, 1991).

Costa et al. (2012) citaram que o sistema de criação extensivo traz baixos rendimentos, gerando, no momento do abate, animais com idade avançada e acabamento de carcaça fora do padrão exigido pelo mercado consumidor. Com intuito de expandir o mercado, os produtores estão investindo tanto no manejo nutricional como no melhoramento genético desses animais.

Sousa et al. (2003) descreveram que dentre os diversos fatores necessários para elevar a produtividade temos a escolha de animais de raça especializada, sendo que não existe uma raça ideal que abranja todas as características produtivas desejáveis, por isso a necessidade de estudar as raças buscando cruzamentos que gerem animais com as características desejáveis de cada uma. Da mesma forma, Cunha et al. (2000) analisaram que uma boa forma de conseguir animais com maior peso ao desmame, maior potencial de ganho de peso em confinamento e melhores características de carcaça é através do cruzamento de matrizes com carneiros de aptidão para a produção de carne.

Allen (1991) citou que há uma grande diversidade de raças ovinas, e estas se adaptaram às diferentes formas de manejo e também aos diferentes climas de acordo com a localização geográfica onde são exploradas. É comum a utilização de raças distintas em locais diferentes na procura por cruzamentos que gerem melhor adaptação a determinado ambiente e manejo. Monty Junior et al. (2004) relatam que é necessário conhecer também a tolerância e capacidade de adaptação dessas raças para melhor explorar os cruzamentos e introduzir as raças e cruzamentos mais adequados para cada ambiente.

O cruzamento de ovelhas mestiças (SRD) adaptadas ao clima do Nordeste brasileiro com carneiros de corte é uma excelente alternativa para aumentar a produção de carne, pois animais "híbridos" são mais resistentes e possuem maior velocidade de crescimento. Dessa forma, esses animais conseguem atender um mercado que demanda 
carcaças maiores, mais pesadas, musculosas, com pouca gordura e carne macia, resultado de animais mais jovens ao abate (Cardellino, 1989, citado por Machado et al., 1999).

Barbosa Neto et al. (2010) concluíram em seu estudo que o acasalamento entre animais mestiços entre si (bimestiçagem) teve efeito significativo e negativo, podendo gerar produtos com pior desempenho quanto ao peso ao desmame. A herdabilidade materna teve a mesma tendência que a herdabilidade direta, indicando influência genética da matriz sobre o cordeiro no peso ao nascer e também no peso ao desmame. Os autores constataram que os genes da raça Santa Inês são favoráveis para maior peso dos cordeiros ao nascimento.

Na pesquisa conduzida por Barbosa Neto et al. (2010) com cruzamentos entre as raças Santa Inês, Somalis Brasileira, Dorper e Poll Dorset observou-se a possibilidade de produzir carne de qualidade adequada com raças também selecionadas para a produção de lã. Tais constatações viabilizam a utilização de ovinos laneiros em cruzamentos industriais, visando maximizar a eficiência na produção de carne.

Aguiar (2015) avaliou cordeiros oriundos do cruzamento de ovelhas da raça Santa Inês acasaladas com distintas raças paternas (Dorper, Lacaune ou Multimeat) e conclui que os resultados de desempenho e características quantitativas de carcaça são satisfatórios, sendo o cruzamento industrial uma boa alternativa para elevar a produção de carne ovina no Brasil

\subsection{Bases genéticas estudadas}

\subsubsection{Santa Inês}

A raça Santa Inês (Figura 1.3) é encontrada em todas as regiões do Brasil. Acredita-se que sua origem seja do cruzamento de diversas raças, desde raças crioulas, trazidas com os colonizadores, juntamente com raças africanas deslanadas, além da Morada Nova e Bergamácia, que tem origem italiana. No final da década de 80, adicionaram ainda as raças Somalis e Suffolk nesses cruzamentos (Sousa et al., 2003). Os autores consideram a raça como rústica, pois se adapta bem e reproduz em diversas regiões do Brasil, desde o semiárido nordestino ao cerrado ou zona tropical, possuindo além da resistência a endoparasitas, 
uma ótima qualidade de pele e bom ganho de peso. Por isso é bastante utilizada em programas de seleção, melhoramento e cruzamento.

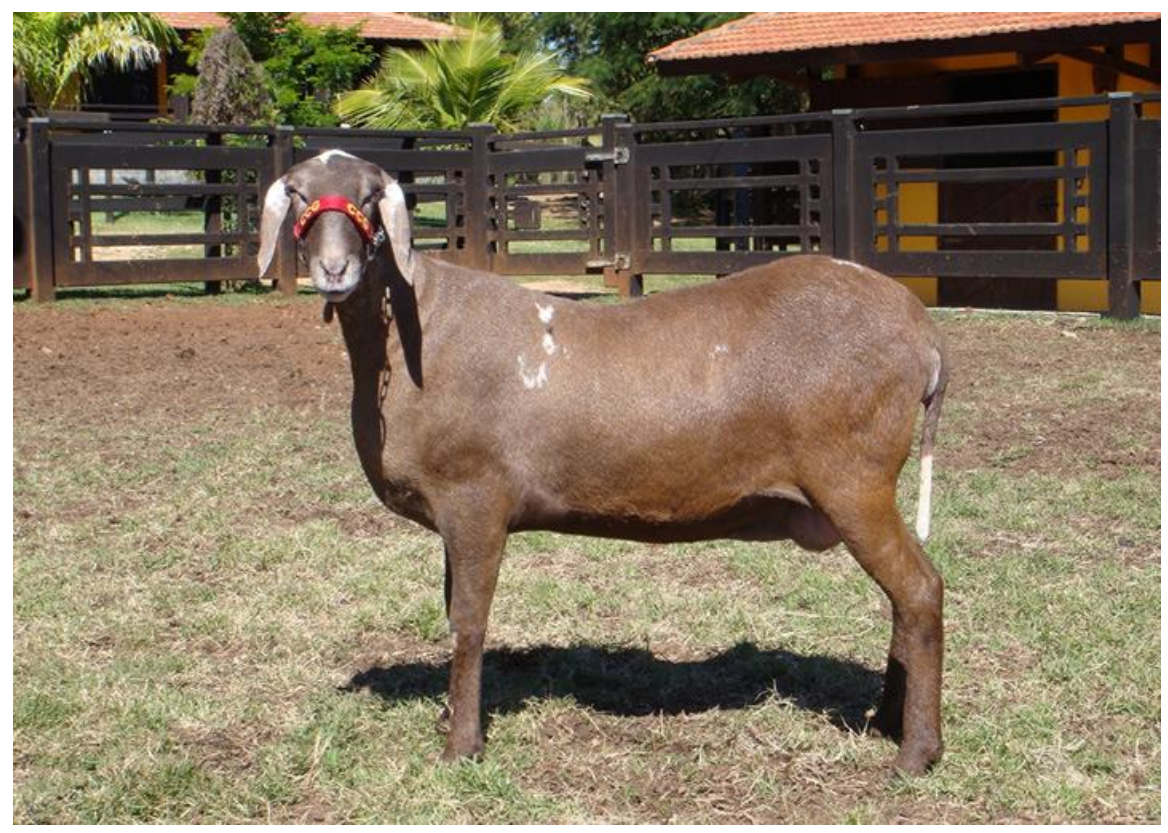

Figura 1.3: Raça Santa Inês

Fonte: http://www.campeasdagameleira.com.br/ovinos.php

Sousa et al. (2003) também mencionaram que a pele da raça Santa Inês é um produto bastante utilizado para produtos manufaturados, como calçados e vestuários, equivalendo a $30 \%$ do valor total do animal por possuir alto padrão. Outro importante fator destacado pelos autores são as perspectivas promissoras no mercado interno que tem levado a raça a ser muito utilizada em cruzamentos como raça materna, devido a sua boa aptidão, complementando o cruzamento com reprodutores de raças especializadas em produção de carne, visando melhorar a conformação que não é um ponto forte da raça Santa Inês.

Santa Inês é uma excelente alternativa para cruzamento com reprodutores de raças com aptidão para carne, como Texel e Ile de France, pois com o cruzamento as características inferiores da raça, como deposição de gordura e conformação da carcaça, são balanceadas e dessa forma se eleva o desempenho da geração F1 (Furusho-Garcia et al., 2004). Além disso, Pinheiro \& Jorge (2010) mencionaram que a raça Santa Inês é muito utilizada no Brasil para produção de carne devido a sua fácil adaptação à maioria das regiões brasileiras e por apresentar bons resultados de produção e qualidade de carne. 
No estudo conduzido por Sousa et al. (2008) observou-se que a raça Santa Inês apresentou descentes da geração F1com melhor conformação de carcaça quando utilizada no cruzamento com Dorper do que os cordeiros cruzamento Santa Inês x Santa Inês, comprovando que a raça pode ser melhor aproveitada se utilizada como raça materna em cruzamentos industriais.

Barbosa Neto et al. (2010) observaram em seu estudo que o efeito médio dos genes da raça Santa Inês resulta em maior peso dos filhotes ao nascimento se comparado com as raças Poll Dorset e Somalis Brasileira.

\subsubsection{Dorper}

De origem sul-africana, a raça Dorper foi desenvolvida em meados de 1930, resultado do cruzamento das raças Dorset Horn e Blackhead Persian (conhecida no Brasil como Somalis Brasileira), com objetivo de obter animais com maior eficiência produtiva às exigências do mercado. A pelagem possui coloração branca, podendo ter a cabeça de coloração preta no Dorper padrão ou cabeça branca no Dorper branco (Figura 1.4). A raça foi introduzida no Nordeste do Brasil no fim dos anos 90 por uma empresa de pesquisa que estudou a adaptabilidade da raça ao clima semi-árido da região com o objetivo de futuros cruzamentos (Rosanova et al., 2005).

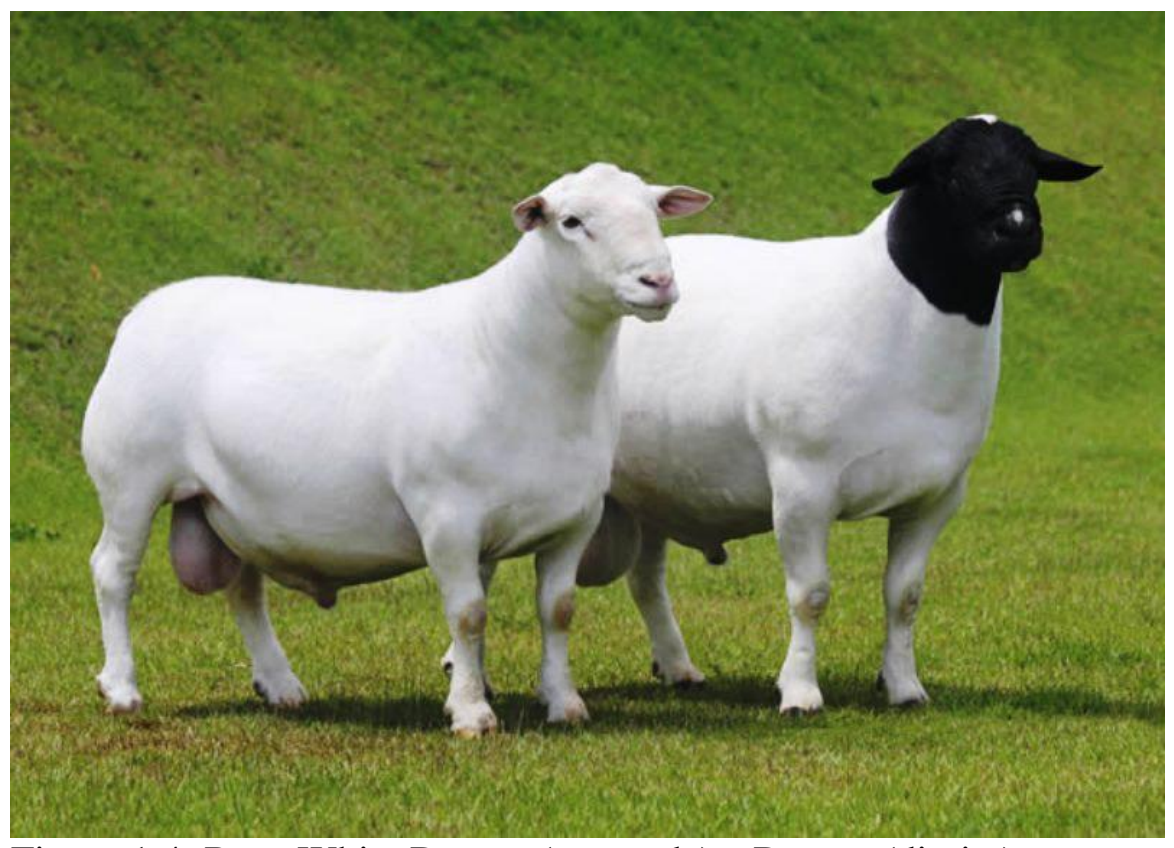

Figura 1.4: Raça White Dorper (esquerda) e Dorper (direita)

Fonte: http://www.cearaagora.com.br/site/2014/07/ 
Rosanova et al.(2005) mencionaram que uma grande vantagem da raça é sua fácil adaptação aos diferentes climas e regiões e também a diferentes formas de manejo. Está entre as raças ovinas de maior fertilidade, com altas taxas de reprodução e grande velocidade de crescimento, e possui grande desenvolvimento de massa muscular. Dados afirmam que os animais podem alcançar $35 \mathrm{Kg}$ em 110 dias de vida.

Sousa (2008) citou a raça Dorper como excelente raça paterna para cruzamentos com matrizes de raça Santa Inês por promover melhor conformação de carcaça nos mestiços F1, gerando carne de melhor qualidade.

Costa et al. (2012) em estudo com sistema extensivo na época do ano de maior disponibilidade de pastagem, observou que animais mestiços Dorper x Santa Inês tiveram peso ao nascer, peso a desmame e ganho de peso total superior ao de cordeiros puros da Santa Inês.

\subsubsection{Ile de France}

A raça Ile de France tem sua origem na França e foi introduzida no Brasil no ano de 1973 com a importação de animais para elevar a qualidade do rebanho local. Inicialmente foi considerada como raça de dupla aptidão para carne (60\%) e lã (40\%), porém atualmente tem sido utilizada exclusivamente como raça de aptidão para carne (Maturano, 2003).

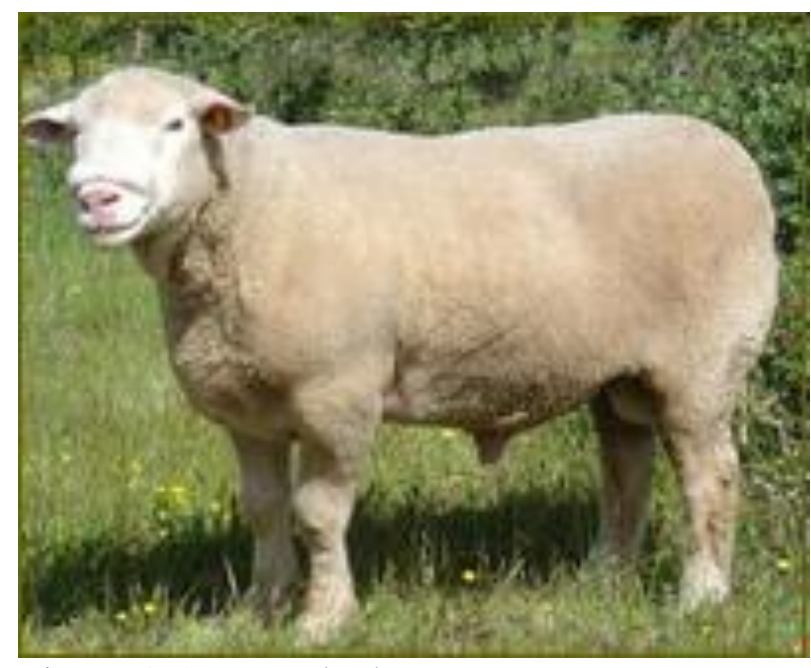

Figura 1.5: Raça Ile de France

Fonte: http://www.arcoovinos.com.br/sitenew/racas 
Maturano (2003) também citou que, por ser uma raça rústica e prolífera, tem sucesso tanto no manejo extensivo como no semi-intensivo, produzindo carcaças de excelente qualidade e com baixa cobertura de gordura. Outro ponto positivo é o fato de ser uma raça precoce, apresentando ganho de peso médio diário de $300 \mathrm{~g}$ (machos) e $275 \mathrm{~g}$ (fêmeas), entre 30 e 90 dias de idade. Aos 70 dias de idade já apresentam uma média de $25 \mathrm{~kg}$ de peso vivo, e quando adultos atingem de 110 a $120 \mathrm{~kg}$ nos machos e de 80 a $90 \mathrm{~kg}$ nas fêmeas.

A raça Ile de France é especializada para corte e boa para cruzamento industrial como raça paterna, pois gera crias mais pesadas ao nascimento e desmame e, por consequência, elevado peso quando mais velhos. Em estudos foi comprovado aumento do comprimento e da compacidade da carcaça (Cunha et al. 2000). Os mesos autores citaram em sua pesquisa que Güney (1990) conseguiu aumentos no peso e rendimento de carcaça quente e espessura de gordura subcutânea, quando acasalou ovelhas mestiças com carneiros Ile de France.

\subsubsection{Multimeat}

O Multimeat (Figura 1.6) é um composto formado por várias raças, entre as principais o White Suffolk. Seu grande diferencial é possuir duas cópias do gene Booroola de fertilidade, gerando $60 \%$ mais nascimentos múltiplos. Dessa forma ao final tem-se um maior retorno financeiro, inclusive também permitindo maior produtividade em rebanhos pequenos (Multimeat, 2015).

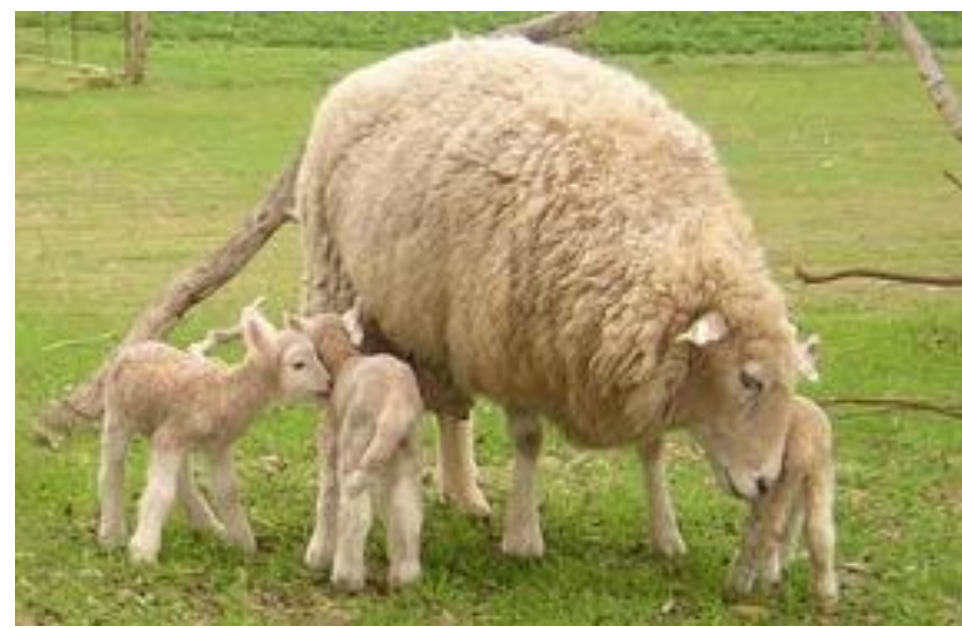

Figura 1.6: Raça Multimeat

Fonte: http://www.woolumbool.com.au/multimeats.html 
A replicação do gene Booroola começou na SARDI (Investigação e Desenvolvimento Instituto da Austrália do Sul), onde perceberam que esse gene agia diretamente no ovário das ovelhas, fazendo com que liberassem mais óvulos. Descobriu-se também que é possível sua transmissão hereditária (Figura 1.7), e que o macho passa esse gene para todas suas filhas. O Boorola chegou à Austrália através de ovelhas vindas da Índia, porém só foi descoberto na década de 1970. Sua replicação é um projeto longo e recente, por isso ainda existem poucos estudos e dados sobre esse gene; no entanto, muitos países já estão utilizando-o pra aprimorar a produção de cordeiros (Grindlay, 2014) e produzir animais a parti do cruzamento com reprodutores da raça Multimeat.

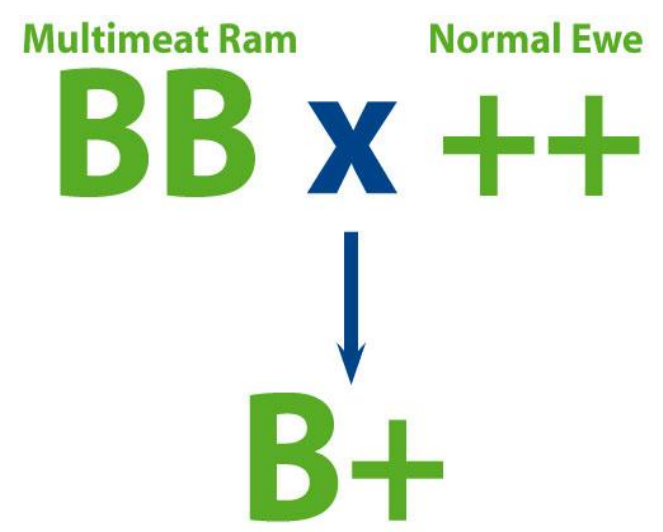

Figura 1.7: Transferência vertical do Gene booroola Fonte: http://www.woolumbool.com.au/multimeats.html

O composto de raças Multimeat foi inicialmente desenvolvido pelo cientista Colin Earl, que estudou o gene Booroola. O pesquisador mencionou que o mestiço ideal gera dois cordeiros nascidos por parto, sendo um só pouco e três, demais. Com dois cordeiros o número de sobreviventes é elevado. Esses animais serão certamente aceitos na indústria, desde que tenham manejo adequado. $\mathrm{O}$ pesquisador também citou que a chave para o bom desempenho desses animais é o suporte nutricional das fêmeas durante a gestação, principalmente no terço final (Miller, 2013).

Aguiar (2015) conduziu uma pesquisa com cordeiros F1 provenientes de cruzamentos de ovelhas da raça Santa Inês tendo a raça paterna carneiros Multimeat e concluiu que a utilização da raça em cruzamentos industriais proporcionou características de carcaça muito satisfatórias em animais provenientes de parto duplo. 


\subsection{Medidas biométricas}

Ao se tratar de características biométricas de ovinos deve-se pensar diretamente em funções econômicas e produtivas. Essas características externas mudam de acordo com a função desejada para esses animais. As características ideais para ovinos produtores de carne são: esqueleto fino, corpo longo e amplo, cabeça leve e membros curtos, linha dorsal horizontal e larga, garupa e nádegas volumosas, costelas compridas e convexas, com corpo de formato retangular quando visto de perfil e forma de $\mathrm{U}$ invertido quando visto de cima, denotando convexidade da musculatura (Rosanova et al., 2005).

Para alcançar as características desejadas evitam-se idades muito avançadas e/ou alta deposição de gordura na carcaça, característica fundamental para o consumidor moderno, que não tolera carnes com elevadas quantidades de tecido adiposo. Um fator que influencia o ganho de peso é a deposição de massa muscular dos animais e, consequentemente, o período de sua formação (Zundt, 2006).

Dentre as medidas biométricas "in vivo" encontram-se: perímetro torácico, largura do peito e da garupa, que estão altamente correlacionadas ao peso corporal ao abate e de carcaça fria de ovinos. Dessa forma o produtor pode utilizar essa ferramenta como forma de calcular o peso médio dos animais sem a necessidade de uma balança (Pinheiro \& Jorge, 2010). Essas medidas apresentam alta correlação com as da carcaça e podem ser utilizadas em conjunto ou separadamente (Cunha et al., 1999).

Avaliando a condição corporal do animal vivo é possível estimar a quantidade de músculo e gordura em relação à óssea, buscando o melhor momento para o abate desses animais (Pinheiro et al., 2007). As medidas biométricas obtidas "in vivo" podem apresentar alta correlação com o peso do animal e também podem ser utilizada como indicadores de características de rendimento, conformação de carcaça e qualidade em sistemas de classificação de carcaças ovinas (Pinheiro \& Jorge, 2010).

A compacidade corporal é um índice de grande importância, pois avalia de forma objetiva a conformação dos animais vivos através de dois valores fáceis de determinar: peso vivo e comprimento corporal (Pinheiro et al., 2007). Moreno et al. (2010) referem-se às medidas biométricas "in vivo" como importantes parâmetros para predizer características produtivas como peso, rendimento e conformação da carcaça, só não sendo capaz de avaliar características da carcaça. Através dessas medidas obtidas do animal vivo, como comprimento corporal, altura do anterior, altura do posterior, perímetro torácico, largura da garupa e conformação é possível determinar o melhor momento para o abate dos animais. 


\section{REFERÊNCIAS BIBLIOGRÁFICAS}

AGUIAR, L. F. G. Desempenho e características da carcaça e da carne de cordeiros de diferentes grupos genéticos. 2015. 68 p. Dissertação (Mestrado) Faculdade de Agronomia e Medicina Veterinária - FAV- Universidade de Brasília (UnB), 2015.

ALLEN, P. La calidad de carne de ovino: el concepto CEE. Mundo Ganadero, Madrid, v.4, p.37-44, 1991.

ALVES, K.S.; CARVALHO, F.F.R.; FERREIRA, M.A. et al. Níveis de Energia em Dietas para Ovinos Santa Inês: Características de Carcaça e Constituintes Corporais. Revista Brasileira de Zootecnia., v.32, n.6, p.1927-1936, 2003 (Supl. 2)

BARBOSA NETO, A.C; OLIVEIRA, S.M.P; FACÓ, O., et al. Efeitos genéticos aditivos e não-aditivos em características de crescimento, reprodutivas e habilidade materna em ovinos das raças Santa Inês, Somalis Brasileira, Dorper e Poll Dorset. Revista Brasileira de Zootecnia, v.39, n.9, p.1943-1951, 2010.

BUENO, M.S.; CUNHA, E.A.; SANTOS, L.E. et al. Características de carcaça de cordeiros Suffolk abatidos em diferentes idades. Revista Brasileira de Zootecnia, v. 29, n. 6, p. 1803$1810,2000$.

CEZAR, M. F.; SOUZA, B. B.; SOUZA, W. H., et al. Avaliação de parâmetros fisiológicos de ovinos Dorper, Santa Inês e seus mestiços perante condições climáticas do trópico semiárido nordestino. Ciência e Agrotecnologia, v.28, n.3, p.614-620, 2004.

COSTA, D.S.; COSTA, M.D.; SILVA, F.V., et al. Desempenho ponderal de cordeiros Santa Inês e F1 Dorper x Santa Inês em pastagens naturais. Revista Brasileira de Saúde e Produção Animal [online], v.13, n.1, p.237-243, 2012.

COSTA, Q.P.B.; WECHSLER, F.S.; COSTA, D.P.B. et al. Desempenho e características da carcaça de bovinos alimentados com dietas com caroço de algodão. Arquivo Brasileiro Medicina Veterinária Zootecnia, v.63, n.3, p.729-735, 2011.

CUNHA, E.A.; SANTOS, L.E.; BUENO, M.S. et al. Utilização de carneiros de raças de corte para obtenção de cordeiros precoces para abate em plantéis produtores de lã. Revista Brasileira de Zootecnia, v.29, n.1, p.243-252, 2000. 
DIAS, M; NASCIMENTO, V.A.A. Influência da nutrição na qualidade da carne. VI Congresso Latino-Americano de Nutrição Animal. Setembro de 2014 - Estância de São Pedro, SP.

EMBRAPA NOTICIAS 2016. Estudo aponta tendências para caprinocultura e ovinocultura nos cenários nacional e internacional. Acesso em:< https://www.embrapa.br/busca-denoticias/-/noticia/8698648/estudo-aponta-tendencias-para-caprinocultura-e-ovinocultura-noscenarios-nacional-e-internacional. Disponível em: 11/08/2016.

FERRÃO, S. P. B.; BRESSAN, M. C.; OLIVEIRA, R. P. et al. Características sensoriais da carne de cordeiros da raça Santa Inês submetidos a diferentes dietas. Ciência e Agrotecnologia, v. 33, n. 1, p. 185-190, 2009.

FURUSHO-GARCIA, I. F. PEREZ, J.R.O.; BONAGURIO, S., et al. Desempenho de cordeiros Santa Inês puros e cruzas Santa Inês com Texel, Ile de France e Bergamácia. Revista Brasileira de Zootecnia. v.33, n.6, p.1591-1603, 2004.

GRINDLAY, D. 2014. South Australian scientist and farmer creates new breed of highly reproductive shedding sheep. Disponível em:<http://www.abc.net.au/news/2014-0901/scientist-come-farmer-creates-new-breed-of-easycare-sheep/5709732>, Acesso em: 09/08/2016.

IBGE - INSTITUTO BRASILEIRO DE GEOGRAFIA E ESTATÍSTICA. 2014. Disponível em: <http://www.sidra.ibge.gov.br> Acesso em: 20/07/2016.

LEMOS NETO, M J.; SIQUEIRA, E R.; FERNANDEZ, S. et al. Caracteres qualitativos da carne de cordeiros da raça Corriedale e mestiços Ile de France x Corriedale, terminados em confinamento. Boletim de Indústria Animal, v.58, n.1, p.83-94, 2001

LOPES, M.A.; MAGALHÃES, G.P. Análise da rentabilidade da terminação de bovinos de corte em condições de confinamento: um estudo de caso. Arquivo Brasileiro Medicina Veterinária Zootecnia, v. 57, n.3, p. 374-379, 2005.

MARQUES, A.V.M.S.; COSTA, R.G.; SILVA, A.M.A. et al. Feno de flor de seda (Calotropis procera SW) em dietas de cordeiros Santa Inês: Biometria e rendimento dos componentes não-constituintes da carcaça. Revista Brasileira de Ciências Agrárias, n.1, v.3, p.85-89, 2008.

MATURANO, A. M. P. Estudo do efeito do peso de abate na qualidade da carne de cordeiros das raças Merino Australiano e Ile de France $x$ Merino / Arlei Maçal Provinciali Maturano. , 2003. 94 p. Dissertação (Mestrado) - Universidade Federal de Lavras (UFLA) 2003.

MILLER, C. 2013. Multimeat boosts flock. Disponível em:< http://www.stockandland.com.au/story/3556758/multimeat-boosts-flock>, Acesso em $: 11 / 08 / 2016$.

MORENO, G.M.B.; SILVA SOBRINHO, A.G.; ROSSI, R .C. et al. Desempenho e rendimentos de carcaça de cordeiros Ile de France desmamados com diferentes idades. Revista Brasileira de Saúde e Produção Animal, v.11, p.1105-1116, 2010.

MULTIMEAT. 2015. Disponível em: <http://www.multimeat.com.au/index.html.> Acesso em: 20/07/2016. 
OLIVEIRA, A.C; SILVA, R.R; OLIVEIRA, H.C., et al. Influência da dieta, sexo e genótipo sobre o perfil lipídico da carne de ovinos. Archivos de Zootecnia 62 (R): 57-72. 2013.

PAIM, T.P.; CONCEPTA, M.; LOUVANDINI, H. Confinamento de Cordeiros. Disponívelem: $<$ http://inctpecuaria.com.br/images/informacoestecnicas/serie_tecnica_confina mento_cordeiros.pdf>.Publicado em: 30/09/2010. Acesso em :15/09/2016.

PINHEIRO, R.S.B., JORGE, A.M. Medidas biométricas obtidas in vivo e na carcaça de ovelhas de descarte em diferentes estágios fisiológicos. Revista Brasileira de Zootecnia v.39, n.2, p.440-445, 2010.

PINHEIRO, R.S.B.; SILVA SOBRINHO, A.G.; MARQUES, C.A.T. et al. Biometría in vivo e da carcaça de cordeiros confinados. Archivos de Zootecnia, v.56 n.216, p.955-958. 2007.

PIRES, C.C.; SILVA, L.F.; SCHLICK, F.E. et al. Cria e terminação de cordeiros confinados. Ciência Rural, v.30, n.5, p.875-880, 2000.

ROSANOVA, C.; SILVA SOBRINHO, A.G.; GONZAGA NETO, S. Raça Dorper e sua caracterização produtiva e reprodutiva. Revista Veterinária Notícias, Uberlândia, v. 11, n. 1, p. 127-135, 2005.

SIQUEIRA, E.R.; FERNANDES, S. Peso, rendimentos e perdas da carcaça de cordeiros Corriedale e mestiços Ile de France $\mathrm{X}$ Corriedale, terminados em confinamento. Ciência Rural, v.29, n.1, p. 143-148, 1999.

SOUSA, W. H.; CARTAXO, F. Q.; CEZAR, M. F. et al. Desempenho e característica de carcaça de cordeiros terminados em confinamento com diferentes condições corporais. Revista Brasileira de Saúde e Produção Animal, v.9, n.4, p.795-803, 2008.

SOUSA, W.H.; LÔBO, R.N.B.; MORAIS, O.R. Ovinos Santa Inês: Estado e Arte e Perspectivas. In: II SIMPÓSIO INTERNACIONAL SOBRE CAPRINOS E OVINOS SINCORTE, 2003. João Pessoa - PB Anais... João Pessoa: SINCORTE, p. 501 - 521, 2003.

VIANA, J.G.A. Panorama Geral da Ovinocultura no Mundo e no Brasil. Revista Ovinos, Ano 4, $\mathrm{N}^{\circ}$ 12, Porto Alegre, Março de 2008. Disponível em: <http://www.caprilvirtual.com.br/Artigos/panorama_geral_ovinocultura_mundo_brasil.pdf>, Acesso em: 18/09/2016.

YAMAMOTO, S.M.; SILVA SOBRINHO, A.G.; VIDOTTI, R.M. et al. Desempenho e digestibilidade dos nutrientes em cordeiros alimentados com dietas contendo silagem de resíduos de peixe. Revista Brasileira de Zootecnia, v.36, n.4, p.1131-1139, 2007 (supl.)

ZUNDT,M.; MACEDO, F.A.F.; ASTOLPHI, J.L.L., et al. Desempenho e características de carcaça de cordeiros Santa Inês confinados, filhos de ovelhas submetidas à suplementação alimentar durante a gestação. Revista Brasileira de Zootecnia, v.35, n.3, p.928-935, 2006. 
CAPITULO 2 


\title{
RESUMO \\ DESEMPENHO E MEDIDAS BIOMÉTRICAS DE CORDEIROS DE DIFERENTES GRUPOS GENÉTICOS TERMINADOS EM CONFINAMENTO
}

\begin{abstract}
Anne Caroline Oliveira Barbosa, Clayton Quirino Mendes ${ }^{1}$
${ }^{1}$ Faculdade de Agronomia e Medicina Veterinária da Universidade de Brasília, Brasília/DF.

Objetivou-se com esse estudo avaliar o desempenho e as medidas biométricas "in vivo" de cordeiros de três diferentes grupos genéticos mantidos em sistema de confinamento. Foram utilizados 24 cordeiros machos e não castrados, formando três tratamentos: 1) Santa Inês $x$ Dorper, 2) Santa Inês x Ile de France e 3) tricross ( $1 / 4$ Santa Inês + 1/4 Dorper +1/2 Multimeat), com peso corporal inicial em torno de $20 \mathrm{~kg}$ e médio de idade de 70 dias, distribuídos em um delineamento inteiramente casualizado (DIC). O experimento teve duração de 76 dias, sendo 10 dias de adaptação dos animais ao manejo e 66 dias de período experimental. A relação volumoso concentrado foi de 30:70. Ao término do período experimental, os animais foram pesados para obtenção do peso final e realização das seguintes medidas biométricas comprimento corporal; altura do anterior; altura do posterior; perímetro torácico; largura da garupa; largura do tórax. O índice de compacidade corporal foi calculado a partir da relação peso final/comprimento corporal. Os animais do grupo genético SI x DO apresentaram peso final superior, os animais tricross menor peso final, enquanto que nos animais SI x ILE o peso final não diferiu dos demais. As variáveis ganho de peso médio diário, ganho de peso total, consumo de matéria seca, conversão alimentar e eficiência alimentar não foram influenciadas pelos grupos genéticos. Nos resultados referentes às medidas biométricas "in vivo" os valores encontrados foram semelhantes entre os grupos genéticos avaliados. Somente na variável altura de anterior houve diferença $(\mathrm{P}<0,05)$, sendo que os animais do tratamento SI x DO apresentaram valores superiores. O cruzamento industrial de ovelhas da raça Santa Inês com machos de raças para aptidão de carne (Dorper, Ile de France ou Multimeat) é eficaz para produção de cordeiros em sistema de confinamento.
\end{abstract}

Palavres-chave: compacidade corporal, conversão alimentar, cruzamento industrial, ganho de peso, multimeat, ovinos. 


\section{ABSTRACT \\ PERFORMANCE AND BIOMETRIC CHARACTERISTICS OF FEDLOT LAMBS FROM DIFFERENT GENETIC GROUPS \\ Anne Caroline Oliveira Barbosa, Clayton Quirino Mendes ${ }^{1}$ \\ ${ }^{1}$ School of Agronomy and Veterinary Medicine - University of Brasilia, DF}

The objective of this study was to evaluate the performance and biometric measures "in vivo" of lambs of three different genetic groups feedlot system. 24 lambs were used and not castrated, forming three treatments: 1) Santa Inês x Dorper, 2) Santa Inês x Ile de France and 3) tricross $(1 / 4$ Santa Inês $+1 / 4$ Dorper Multimeat $+1 / 2)$, with initial body weight around $20 \mathrm{~kg}$ and average age of 70 days, distributed in a completely randomized design (CRD). The experiment lasted 76 days, 10 days of adaptation of animals to management and 66-day trial. The concentrate roughage was 30:70. At the end of the experimental period, the animals were weighed to obtain the final weight and achievement of the following biometric measurements body length; height above; the later time; Girth; width of the croup; width of the thorax. Body compactness index was calculated from the relationship final / body length weight. The genetic groups SI x DO showed higher final weight, the animals tricross lower final weight, whereas in SI x ILE animals final weight did not differ from the others. The variables average daily gain, total weight gain, dry matter intake, feed conversion and feed efficiency were not affected by genetic groups. The results of the biometric measures "in vivo" the values were similar among genetic groups evaluated. Only the previous variable height difference $(\mathrm{P}$ $<0.05$ ), and the animals of the SI x OF treatment showed higher values. The crossbreeding of ewes Santa Ines with breeds of males for meat fitness (Dorper, Ile de France or Multimeat) is effective for production of lambs in feedlot.

keywords: body compactness, feed, industrial crossing, weight gain, multimeat, sheep. 


\section{INTRODUÇÃO}

Ovinos possuem um elevado potencial produtivo, e estudos científicos comprovam que o cordeiro (animal jovem) é a categoria com maiores rendimentos de carcaça e maior eficiência de produção, além de produzirem uma carne de melhor qualidade. Dentre os fatores importantes para o alcance dessa carne de alta qualidade, além da raça e idade ao abate, o confinamento tem se mostrado uma importante ferramenta para conseguir maior produtividade desses animais (Pires et al, 2000).

Quando se pensa em produtividade é de extrema importância avaliar o ganho de peso do animal, o consumo de matéria seca e a conversão alimentar, pois dessa forma é possível otimizar a produção e aumentar os lucros (Furusho-Garcia et al., 2004).

Araújo Filho et al. (2010) relataram que estudos já comprovam que o Brasil possuí índices satisfatórios de produção quando utiliza raças e cruzamentos corretos associados a um bom manejo. Os autores supracitados também mencionaram que quando se trabalha com melhoramento genético é indispensável fazer a caracterização fenotípica dos grupos raciais estudados.

Essa caracterização pode ser realizada através de medidas morfométricas, coloração dos animais, índices zootécnicos e desempenhos de acordo com o sexo e a categoria. Esses índices são importantes para se estabelecer a conformação e funcionalidade do animal (Araújo filho, 2007).

Pinheiro et al. (2007) citaram que é possível avaliar a proporção de músculos de um animal através de suas medidas biométricas, um método de avaliação barato e fácil que permite prever o melhor momento para o abate além da comparação entre raças, dietas e manuseio. Outro índice de fácil mensuração é a compacidade corporal, onde se estima 
objetivamente a conformação dos animais vivos utilizando o peso vivo e o comprimento corporal.

O desempenho produtivo é de fundamental importância quando se trabalha com cordeiros, pois é o responsável por determinar o retorno econômico que a criação de ovinos irá trazer para o produtor. As características responsáveis por influenciar o desempenho produtivo são: raça, ganho de peso, genética e fenotípica (Rosanova et al., 2005).

Costa et al. (2012) ressaltaram a importância de acompanhar, avaliar e analisar os animais desde o nascimento, pois o peso ao nascer e ao desmame é essencial na seleção de ovinos. Com esses valores é possível analisar o desempenho desses cordeiros e também a habilidade materna da ovelha. Os autores também mencionam que uma maneira de elevar o ganho de peso médio diário de cordeiros é através da inclusão de concentrado na dieta.

Dessa forma, objetivou-se com o presente estudo avaliar o desempenho produtivo e as medidas biométricas corporais de cordeiros de três diferentes grupos genéticos mantidos em sistema de confinamento. 


\section{MATERIAL E MÉTODOS}

O experimento teve duração de 76 dias (01 de Setembro a 16 de Novembro de 2015) e foi realizado no Centro de Manejo de Ovinos (CMO) da Fazenda Água Limpa (FAL), de propriedade da Universidade de Brasília (UnB), localizada na cidade de Brasília-DF.

A classificação do clima é Aw segundo a Köppen e Geiger e a temperatura média em Brasília é de $21,1{ }^{\circ} \mathrm{C}$. Durante a realização do experimento e de acordo com a estação meteorológica da FAL, a média de pluviosidade foi de $44,5 \mathrm{~mm}$, a temperatura média de $22,9{ }^{\circ} \mathrm{C}$ e a umidade relativa do ar $58 \%$.

Os animais foram alojados em sistema de confinamento em baias individuais providas de comedouro e bebedouro individual, distribuídos em um galpão de alvenaria com cobertura metálica, protegidos de chuvas e ventos.
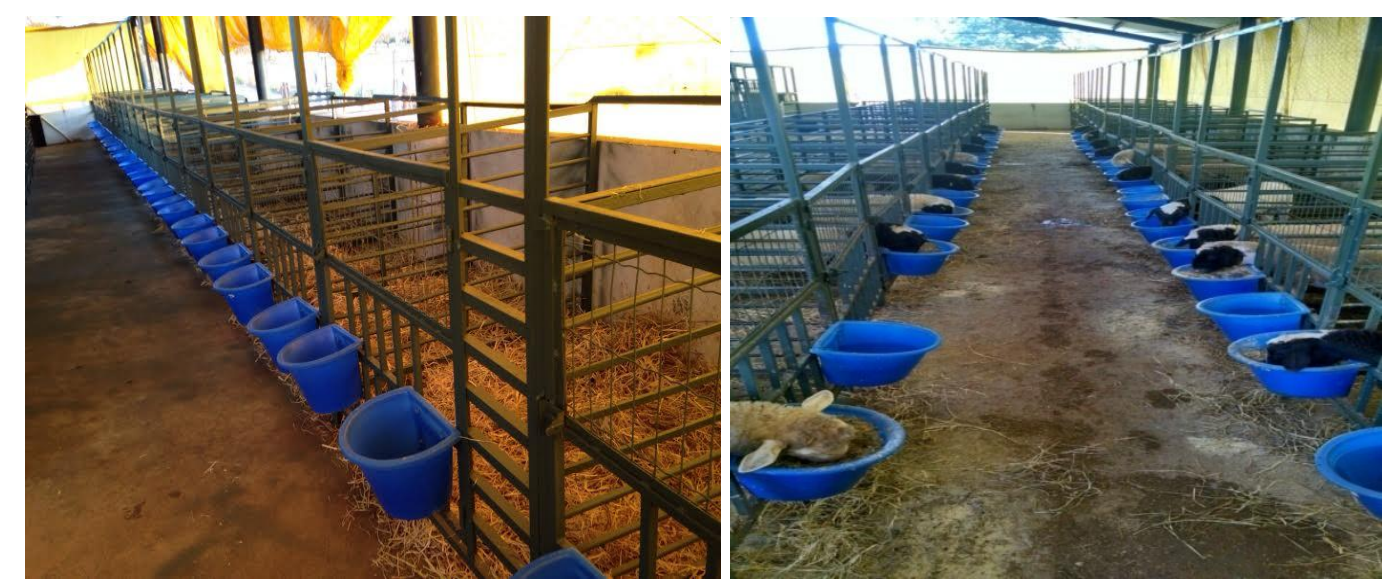

Figura 2.1: Instalações experimentais

Fonte: arquivo pessoal 
Utilizou-se 24 cordeiros machos e não castrados de três diferentes grupos genéticos, formando assim os tratamentos: 1) 1/2Santa Inês x 1/2Dorper, 2) 1/2Santa Inês x 1/2Ile de France e 3) "tricross" (1/4 Santa Inês + 1/4 Dorper +1/2Multimeat), com peso corporal inicial em torno de $20 \mathrm{~kg}$ idade média de 70 dias. Todos os animais foram vermifugados antes do início do experimento e distribuídos em um delineamento inteiramente casualizado (DIC).

Os animais foram submetidos a 10 dias de adaptação ao sistema de confinamento (dieta e instalações), mais 66 dias divididos em três períodos de 22 dias experimentais. Os animais foram pesados no início do experimento e ao final de cada período experimental, a fim de monitorar o ganho de peso (desempenho) e os ajustes na quantidade de alimentos fornecidos.

As rações experimentais foram formuladas de acordo com recomendações do AFRC (Agricultural and Food Research Council - 1998) para atender as exigências nutricionais em proteína e energia metabolizável e proporcionar um ganho de peso em torno de 250 gramas/dia. A relação volumoso concentrado foi de 30:70, sendo o volumoso utilizado a silagem de milho e o concentrado à base de farelo de soja (27,8\%), farelo de milho $(68,2 \%)$ e núcleo mineral (4\%). A dieta total apresentou média de 16\% de Proteína Bruta (PB) e $75 \%$ de Nutrientes Digestíveis Totais (NDT).

A ração foi fornecida duas vezes ao dia, às $9 \mathrm{~h}$ e às $15 \mathrm{~h}$. A retirada das sobras ocorreu diariamente antes do fornecimento da ração no período da manhã e foram pesadas, de forma a monitorar a quantidade efetivamente consumida pelos animais. De acordo com o cálculo das quantidades ofertadas e consumidas, as sobras diárias foram de aproximadamente $15 \%$ do fornecido.

Amostras dos ingredientes das rações experimentais e das sobras de cada animal foram coletadas semanalmente, acondicionadas em sacos plásticos, identificadas e congeladas. Posteriormente, realizaram-se análises laboratoriais da matéria seca (MS) das amostras, seguindo metodologia descrita por Silva \& Queiroz (2002). A conversão alimentar (CA) foi calculada utilizando-se a fórmula: quantidade de MS consumida (g) dividida pelo de ganho de peso (g), enquanto que a e eficiência alimentar (EA) foi: ganho de peso (g) dividido pela quantidade de MS consumida (g). 
Ao término do período experimental, os animais foram pesados para obtenção do peso final (PF), e foram realizadas, com uso de fita métrica e compasso, as seguintes medidas biométricas (in vivo):

$\checkmark$ comprimento corporal: distância entre a articulação cérvico-torácica e a base da cauda;

$\checkmark \quad$ altura do anterior: distância entre uma reta medida da cernelha ao solo;

$\checkmark \quad$ altura do posterior: distância entre uma reta medida da garupa ao solo;

$\checkmark$ perímetro torácico: contorno da circunferência torácica medida atrás da paleta;

$\checkmark$ largura da garupa: distância entre os trocânteres maiores dos fêmures;

$\checkmark$ largura do tórax: distância entre as faces laterais das articulações escápulo umerais.

Todas as medidas foram feitas com os animais em superfície plana e horizontal, em condições corretas de aprumo e pelo mesmo avaliador a fim de evitar discrepâncias (Figura 2.2). O índice de compacidade corporal foi calculado a partir da relação peso final/comprimento corporal. 


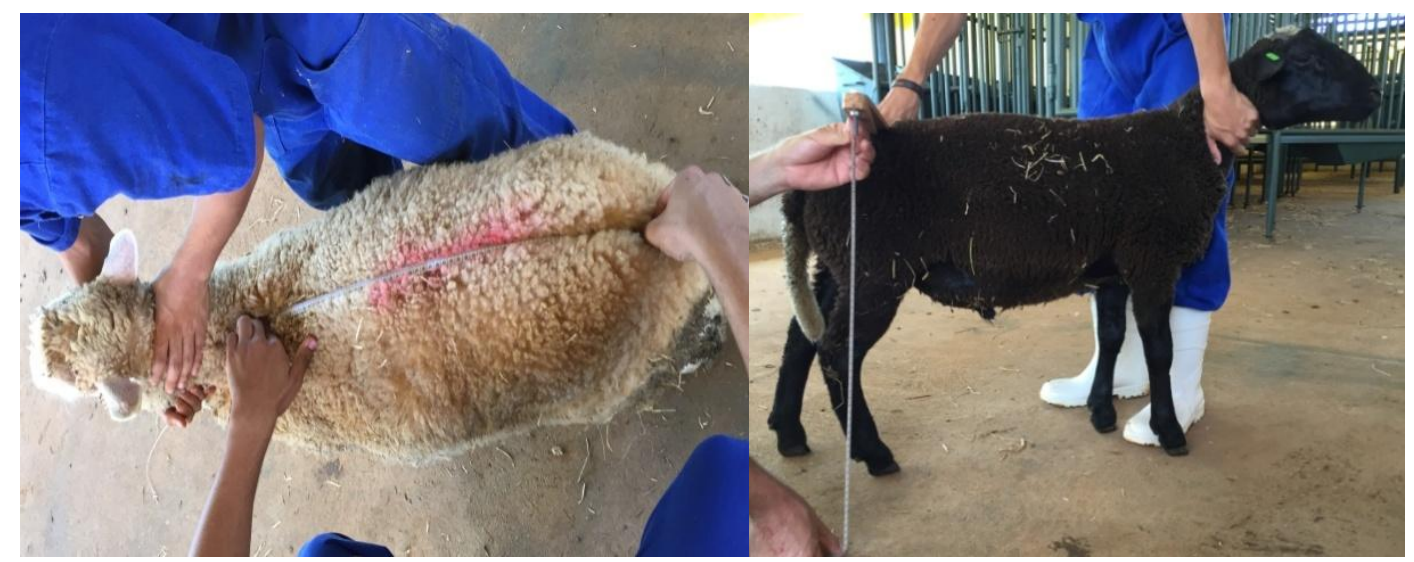

A. Comprimento corporal

B. Altura do posterior

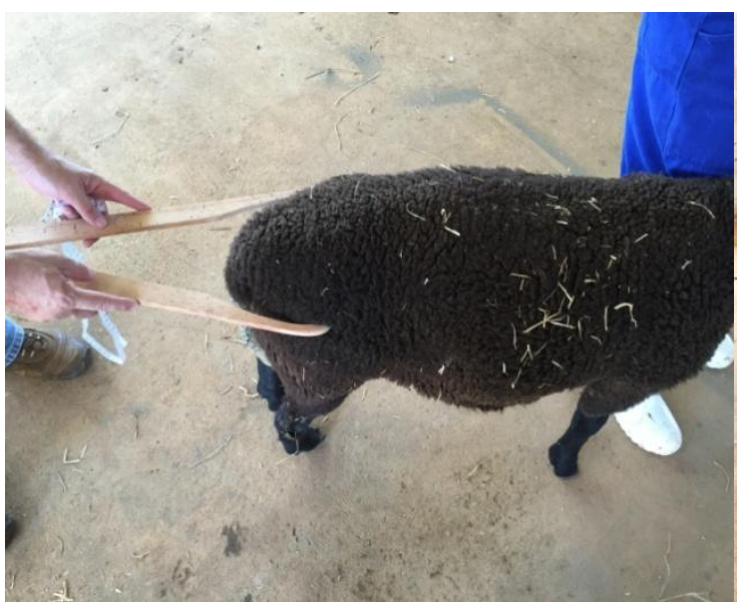

C. Largura de garupa

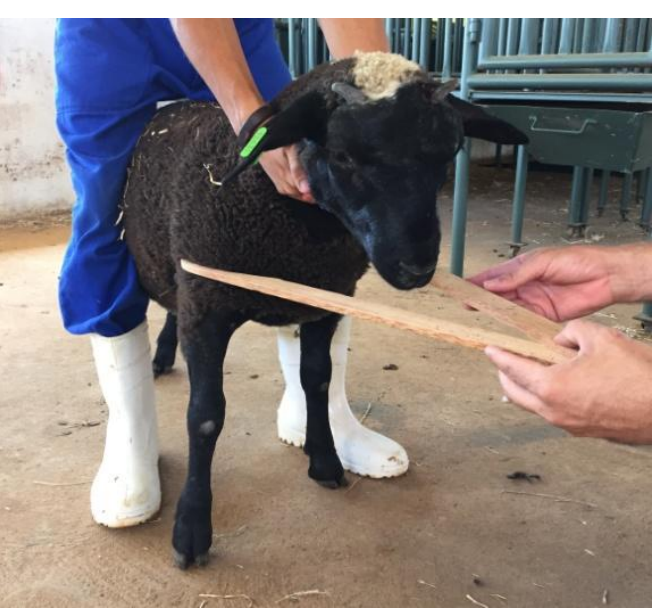

D. Largura do tórax

Figura 2.2: Medidas biométricas "in vivo" Fonte: Arquivo pessoal

O delineamento experimental foi o Inteiramente Casualizado (DIC), utilizandose 24 animais distribuídos em 3 tratamentos. Os dados foram analisados utilizando-se o pelo PROC GLM do programa computacional SAS versão 9.2 (2008). Foram realizadas análises de variância e após verificação da significância do teste $\mathrm{F}$ as médias foram submetidas ao teste de Tukey, adotando-se 5\% de significância. 


\section{RESULTADOS E DISCUSSÃO}

Observa-se na Tabela 1 que somente o peso final (PF) apresentou diferença $(\mathrm{P}<0,05)$, sendo que os animais do grupo genético SI x DO apresentaram peso final superior em relação aos animais tricross, enquanto que os animais SI x ILE não diferiram dos demais.

As demais variáveis (Tabela 1) não foram influenciadas pelos grupos genéticos, apresentando valores médios de 281,10 g/dia para ganho de peso médio diário (GMD), 18,83 kg para ganho de peso total (GPT), 1,50 kg/dia para consumo de matéria seca (CMS), 5,40 para conversão alimentar (CA) e 0,188 para a eficiência alimentar (EA). Vale ressaltar que os resultados obtidos no presente trabalho estão de acordo com os encontrados na literatura, em estudos avaliativos do desempenho produtivo de cordeiros com aptidão para produção de carne e terminados em confinamento.

O presente estudo apresentou resultados para ganho médio diário de peso similar aos 300g/dia do estudo apresentado por Aguiar (2015), que também avaliou o desempenho de cordeiros machos inteiros de três diferentes grupos genéticos (Santa Inês $\mathrm{x}$ White Dorper, Santa Inês x Lacaune e Santa Inês x Multimeat) em sistema de confinamento com dieta fornecida de $25 \%$ de volumoso e $75 \%$ de concentrado. Da mesma forma, a eficiência alimentar (EA) desse estudo apresentou valores $(0,188)$ próximos $(0,174)$ aos do autor supracitado. Já a média do CMS $(\% \mathrm{PV})$ do presente estudo $(4,98)$ foi inferior à observada por Aguiar (2015), de 5,94. 
Tabela 1. Peso inicial e final (kg), ganho de peso médio diário (GPMD, g/dia), ganho de peso total (GPT, $\mathrm{kg}$ ), consumo de matéria seca (CMS. Kg/dia), consumo de matéria seca em porcentagem de peso vivo (CMS, \%PV), consumo de matéria seca em gramas por peso metabólico (CMS, g/PM), consumo de matéria seca em porcentagem de peso metabólico (CMS, \%PM), conversão alimentar (CA), eficiência alimentar (EA) e coeficiente de variação (CV) de cordeiros de diferentes grupos genéticos terminados em confinamento.

\begin{tabular}{lccccc}
\hline \multirow{2}{*}{ Variáveis } & \multicolumn{5}{c}{ Grupo Genético $^{1}$} \\
\cline { 2 - 6 } & SI x DO & SI x ILE & Tricross & CV & $\boldsymbol{P}$ \\
\hline Peso inicial (kg) & $22,54 \pm 3,39$ & $21,29 \pm 3,38$ & $18,83 \pm 3,67$ & 16,54 & 0,182 \\
Peso final (kg) & $42,17 \mathrm{a} \pm 5,03$ & $40,06 \mathrm{ab} \pm 5,28$ & $36,93 \mathrm{~b} \pm 4,57$ & 7,96 & 0,046 \\
GMD (g/dia) & $293,00 \pm 46,80$ & $280,14 \pm 35,39$ & $270,17 \pm 56,15$ & 16,43 & 0,677 \\
GPT (kg) & $19,63 \pm 3,14$ & $18,77 \pm 2,39$ & $18,10 \pm 3,77$ & 16,49 & 0,679 \\
CMS (kg/dia) & $1,56 \pm 0,214$ & $1,52 \pm 0,357$ & $1,43 \pm 0,204$ & 17,93 & 0,701 \\
CMS (\%PV) & $4,83 \pm 0,414$ & $4,94 \pm 0,834$ & $5,16 \pm 0,413$ & 12,03 & 0,618 \\
CMS (g/PM) & $115,08 \pm 9,85$ & $116,10 \pm 20,78$ & $118,32 \pm 9,53$ & 12,55 & 0,922 \\
CMS (\%PM) & $11,51 \pm 0,986$ & $11,61 \pm 2,08$ & $11,83 \pm 0,952$ & 12,52 & 0,921 \\
CA & $5,37 \pm 0,515$ & $5,39 \pm 0,868$ & $5,43 \pm 0,894$ & 14,29 & 0,991 \\
EA & $0,187 \pm 0,019$ & $0,190 \pm 0,034$ & $0,188 \pm 0,029$ & 14,74 & 0,984 \\
\hline
\end{tabular}

Médias seguidas por letras diferentes, dentro de cada linha, diferem pelo teste Tukey $(\mathrm{P}<0,05)$.

${ }^{1}$ SI x DO: Santa Inês x Dorper ; SI x ILE: Santa Inês x Ile de France; Tricross: Mestiço Santa Inês + Dorper x Multimeat (SI+DO x MM).

O estudo conduzido por Sousa (2008) com cordeiros Santa Inês e mestiços Dorper $\times$ Santa Inês não-castrados, com dieta de volumoso:concentrado de 30:70, apresentou melhores resultados de conversão alimentar $(\mathrm{CA}), 3,24$ para Dorper $\times$ Santa Inês, quando comparado com a média de 5,40 do presente estudo, indicando melhor utilização do alimento ingerido pelos animais do estudo de Sousa. Essa diferença de valores pode ter ocorrido pelo de que os animais do estudo de Sousa (2008) tiveram menor consumo de matéria seca (CMS $\mathrm{Kg} / \mathrm{dia}$ ), 0,96kg/dia se comparado com a média de $1,50 \mathrm{~kg} / \mathrm{dia}$ do presente estudo, enquanto que o ganho de peso médio diário (GPMD, g/dia) foi similar nos dois estudos.

Os animais do presente estudo apresentaram valor de ganho médio diário de peso superior ao do estudo conduzido por Araujo Filho et al. (2010) com cordeiros das raças Morada Nova, Santa Inês e mestiços Dorper $\times$ Santa Inês e dieta fornecida para ganhos diários de $250 \mathrm{~g} / \mathrm{dia}$. Provavelmente isso se deve ao fato do consumo de matéria seca ( $\mathrm{Kg} / \mathrm{dia})$ dos animais do presente estudo ter sido superior. A variável de eficiência alimentar também apresentou melhores resultados quando comparada, indicando melhor desempenho produtivo dos animais do presente estudo. 
O estudo conduzido por Pires et al. (2000) com cordeiros machos inteiros, filhos de carneiros Texel e ovelhas cruza Texel x Ideal em sistema de confinamento, com dietas contendo $60 \%$ de volumoso e $40 \%$ de concentrado apresentou valores de 5,96, similares aos 5,40 encontrados no presente estudo para a variável de conversão alimentar. Já o ganho médio diário (GMD) foi de $176 \mathrm{~g} / \mathrm{dia}$, muito inferior ao presente estudo (281 g/dia). Esse menor consumo de MS e ganho de peso diário podem ter ocorrido devido ao fornecimento de $40 \%$ de concentrado e $60 \%$ de volumoso aos animais, enquanto que no presente estudo a relação volumoso: concentrado foi de 30:70, sugerindo que essa maior quantidade de concentrado proporciona maiores ganhos de peso diários e, consequentemente, menor tempo de terminação dos animais.

Moreno et al. (2010) conduziram um experimento com cordeiros da raça Ile de France machos, não castrados, com dieta para ganho de peso médio diário estimado em $300 \mathrm{~g} /$ dia com alimentação composta de $40 \%$ de volumoso e $60 \%$ de concentrado. Os resultados encontrados para variável de ganho médio diário foram de 255 e 312g/dia, inferiores aos 281g/dia do presente estudo, assim como para o consumo de matéria seca $(0,908 \mathrm{~kg} / \mathrm{dia})$, inferior se comparado ao presente estudo, $1,50 \mathrm{~kg} / \mathrm{dia}$. Uma possível explicação para esses menores valores encontrados pelos autores é a maior presença de fibra (40\% de volumoso) na dieta total, que pode ter influenciado no menor consumo de MS e, consequentemente, em menor ganho de peso diário.

Em um experimento conduzido por Queiroz et al. (2008) com cordeiros da raça Santa Inês confinados com tratamento de dietas contendo diferentes fontes proteicas, obtevese $1,17 \mathrm{~kg} /$ dia como média do consumo de matéria seca, inferior à encontrada no presente estudo, 1,50kg/dia. Já o valor da variável de ganho médio diário foi superior ao encontrado nos animais deste experimento, $330 \mathrm{~kg} / \mathrm{dia}$, o que explica o valor de conversão alimentar de 3,53 também melhor do que o do presente experimento.

Os animais do presente estudo apresentaram médias de consumo de matéria seca superiores às observadas por Furusho-Garcia et al. (2004), que trabalharam com cordeiros machos e fêmeas, provenientes de reprodutores das raças Santa Inês, Texel, Ile de France e Bergamácia com ovelhas da raça Santa Inês, confinados com dieta de $80 \%$ de concentrado e $20 \%$ de feno. Já para o coeficiente de conversão alimentar, os dois estudos apresentaram valores similares. Para a variável de ganho médio diário, o presente estudo (281g/dia) apresentou melhor valor que o outro (203 g/dia). Uma possível resposta para isso é 
que no estudo de Furusho-Garcia et al. (2004) o grupo genético Bergamácia apresentou baixos valores, diminuindo a média geral.

Em um estudo realizado por Cardoso et al. (2013) cordeiros machos e fêmeas de três grupos genéticos (Santa Inês, Ile de France x Santa Inês e Texel x Santa Inês), confinados com dieta de $70 \%$ de concentrado e $30 \%$ de volumoso apresentaram menores valores de ganho médio diário $(204,66)$ se comparado com os animais do presente estudo.

$\mathrm{Na}$ análise experimental conduzida por Zundt et al. (2002), utilizando cordeiros machos, inteiros, $1 / 2$ Texel $+1 / 4$ Bergamácia $+1 / 4$ Coriedale, confinados com dieta contendo $16 \%$ de $\mathrm{PB}$, os valores encontrados para ganho médio diário de $0,162 \mathrm{~kg} /$ dia foram inferiores aos encontrados no presente trabalho, de $0,281 \mathrm{~kg} / \mathrm{dia}$. Para a variável de consumo de matéria seca, a média dos valores encontrados para machos $(1,28 \mathrm{~kg} /$ dia) foram próximas aos 1,50 $\mathrm{kg} /$ dia do presente estudo. Já para a variável de conversão alimentar, o presente estudo apresentou o valor de 5,40 em comparação a 8,03 do outro, indicando que os animais do presente experimento tiveram melhor eficiência quanto ao desempenho.

Os animais do presente experimento apresentaram maiores valores para ganho médio diário quando comparado aos do experimento conduzido por Zeoula (2002) com cordeiros da raça Morada Nova em confinamento com alimentação contendo $60 \%$ de concentrado e $40 \%$ de volumoso, que encontrou $0,172 \mathrm{~kg} /$ dia. Uma provável explicação para esse resultado é que o presente estudo utilizou animais mestiços com habilidade para produção de carne, enquanto o outro utilizou animal puro sem características para boa aptidão para produção de carne.

É possível avaliar nesse estudo que os animais provenientes dos três grupos genéticos apresentaram valores satisfatórios para ganho médio diário e eficiência alimentar, características essenciais na avaliação do desempenho animal, alcançando as expectativas dos produtores de animais precoces, além do maior peso ao abate.

De acordo com a Tabela 2, os resultados foram semelhantes para a maioria das variáveis estudadas $(\mathrm{P}>0,05)$ entre os tratamentos referentes às medidas biométricas "in vivo". Somente na altura de anterior houve diferença $(\mathrm{P}<0,05)$, indicando que os animais do tratamento SI x DO apresentaram valores superiores aos cordeiros tricross e os animais oriundos do cruzamento SI x IL não diferiram dos demais. 
Tabela 2. Avaliações biométricas "in vivo": comprimento espanhol (CEsp, $\mathrm{cm})$, comprimento neozolandês $(\mathrm{CNeoz}, \mathrm{cm})$, largura da garupa $(\mathrm{LG}, \mathrm{cm})$, largura do tórax $(\mathrm{LT}, \mathrm{cm})$, comprimento da perna (C. perna, $\mathrm{cm}$ ), altura do anterior (Alt. anterior, $\mathrm{cm}$ ), altura do posterior (Alt. posterior, $\mathrm{cm}$ ), perímetro do tórax (Per. Tórax, $\mathrm{cm}$ ), compacidade corporal $(\mathrm{CCO}, \mathrm{kg} / \mathrm{cm}$ ) e coeficiente de variação (CV) de cordeiros de diferentes grupos genéticos terminados em confinamento.

\begin{tabular}{|c|c|c|c|c|c|}
\hline \multirow{2}{*}{ Variáveis } & \multicolumn{4}{|c|}{ Grupos Genéticos $^{1}$} & \multirow[b]{2}{*}{$\mathbf{P}$} \\
\hline & SI x DO & SI $x$ ILE & SI+DO x MM & $\mathbf{C V}$ & \\
\hline CEsp (cm) & $62,71 \pm 71$ & $60,86 \pm 4,99$ & $62,83 \pm 4,26$ & 6,87 & 0,640 \\
\hline CNeoz $(\mathrm{cm})$ & $65,50 \pm 2,53$ & $61,86 \pm 3,90$ & $63,33 \pm 5,54$ & 6,42 & 0,272 \\
\hline $\mathrm{LG}(\mathrm{cm})$ & $27,18 \pm 1,29$ & $26,93 \pm 0,886$ & $27,00 \pm 1,26$ & 4,27 & 0,913 \\
\hline $\mathrm{LT}(\mathrm{cm})$ & $23,04 \pm 9,22$ & $27,50 \pm 2,10$ & $26,87 \pm 1,04$ & 21,92 & 0,308 \\
\hline C. perna & $49,07 \pm 3,97$ & $47,57 \pm 3,46$ & $46,50 \pm 2,95$ & 7,36 & 0,432 \\
\hline Alt. Anterior & $60,78 \pm 4,54 a$ & $59,50 \pm 3,76 a b$ & $59,03 \pm 2,74 b$ & 6,37 & 0,021 \\
\hline Alt. Posterior & $64,21 \pm 3,96$ & $60,00 \pm 2,33$ & $59,25 \pm 2,82$ & 5,11 & 0,691 \\
\hline Per. Tórax & $80,21 \pm 3,19$ & $80,28 \pm 4,15$ & $79,00 \pm 4,90$ & 5,12 & 0,823 \\
\hline $\mathrm{CCO}(\mathrm{kg} / \mathrm{cm})$ & $0,671 \pm 0,062$ & $0,659 \pm 0,079$ & $0,587 \pm 0,051$ & 10,27 & 0,640 \\
\hline
\end{tabular}

Médias seguidas por letras diferentes, dentro de cada linha, diferem pelo teste Tukey $(\mathrm{P}<0,05)$.

${ }^{1}$ SI x DO: Santa Inês x Dorper ; SI x ILE: Santa Inês x Ile de France; Tricross: Mestiço Santa Inês + Dorper x Multimeat (SI+DO x MM).

As médias encontradas para as medidas biométricas foram: $62,13 \mathrm{~cm}$ de comprimento espanhol, $63,56 \mathrm{~cm}$ de comprimento neozolandês, $27,04 \mathrm{~cm}$ de largura da garupa, 25,80 cm de largura do tórax, $47,71 \mathrm{~cm}$ de comprimento da perna, $59,77 \mathrm{~cm}$ de altura do anterior, $61,15 \mathrm{~cm}$ de altura do posterior, $79,83 \mathrm{~cm}$ de perímetro de tórax e $0,639 \mathrm{~kg} / \mathrm{cm}$ de compacidade corporal.

Pinheiro et al. (2007) avaliaram a morfologia "in vivo" de cordeiros 7/8 Ile de France 1/8 Ideal com peso inicial de $17 \mathrm{~kg}$, terminados em confinamento em gaiolas individuais até atingirem $32 \mathrm{~kg}$ com dietas com relações volumoso: concentrado 50:50 e 30:70. Os autores supracitados encontraram como média de largura de garupa 20,50 cm, enquanto o presente estudo encontrou um valor médio de 27,04 cm. Para largura de tórax, obtiveram o valor de $19,92 \mathrm{~cm}$ contra $25,80 \mathrm{~cm}$ do presente estudo. Para perímetro torácico, encontraram $80,50 \mathrm{~cm}$, similar ao valor de 79,83 do presente estudo. O valor de $61 \mathrm{~cm}$ encontrado para perímetro corporal foi similar ao $62,13 \mathrm{~cm}$ do presente estudo. $\mathrm{O}$ valor de $60,5 \mathrm{~cm}$ foi equivalente ao de $59,77 \mathrm{~cm}$ de altura do anterior, e o de $60,75 \mathrm{~cm}$ também correspondeu aos $61,15 \mathrm{~cm}$ de altura do posterior do presente estudo. Para compacidade corporal os valores encontrados foram $0,50 \mathrm{~kg} / \mathrm{cm}$, inferiores aos $0,639 \mathrm{~kg} / \mathrm{cm}$. Esses valores 
mostram que os animais avaliados por Pinheiro et al. (2007) possuíam uma conformação com menos musculatura que a do presente estudo. Uma explicação para esse resultado seria o maior peso ao abate dos animais do presente estudo.

Moreno et al. (2010) realizaram um estudo com cordeiros da raça Ile de France, machos não-castrados, com peso inicial médio de $15 \mathrm{~kg}$ e seis meses de idade, tratados com $60 \%$ de volumoso para $40 \%$ de concentrado e vice-versa. Os valores encontrados para as variáveis de comprimento corporal, largura de tórax, largura de garupa, perímetro torácico e compacidade corporal foram similares aos do presente estudo: $56,00 \mathrm{~cm}$, $25,23 \mathrm{~cm}, 27,66 \mathrm{~cm}, 77,15 \mathrm{~cm}, 79,83 \mathrm{~cm}$ e $0,56 \mathrm{~cm}$, respectivamente.

Almeida et al. (2015) estudaram cordeiros mestiços de Santa Inês e sem raça definida, machos, inteiros, em sistema de confinamento com $60 \%$ de concentrado e $40 \%$ de volumoso. Obtiveram valores de largura da garupa $(21,38 ; 21,1021,70 ; 22,63 ; 20,60) \mathrm{cm}$ inferiores aos $27,04 \mathrm{~cm}$ do presente estudo. O perímetro torácico de $75 \mathrm{~cm}$ também foi inferior ao valor de 79,83 $\mathrm{cm}$ do presente estudo. Provavelmente essa diferença ocorreu porque os autores supracitados utilizaram animais que não são de aptidão para carne; já no presente estudo foram utilizados cruzamentos industriais com raças de aptidão para corte.

No experimento realizado por Carneiro et al. (2007) com borregos machos e fêmeas de cruzamentos de macho Dorper com fêmeas Morada Nova, Santa Inês e Rabo Largo em sistema de produção semi-intensivo, foram obtidos valores de $14,71 \mathrm{~cm}$ de largura da garupa, 16,63 cm de largura do tórax, $54,62 \mathrm{~cm}$ de altura posterior, $58,01 \mathrm{~cm}$ de perímetro do tórax e 47,46 cm de comprimento corporal, inferiores aos do presente estudo, respectivamente: $27,04 \mathrm{~cm}, 25,80 \mathrm{~cm}, 61,15 \mathrm{~cm}, 79,83 \mathrm{~cm}, 62,13 \mathrm{~cm}$. Isso se deve provavelmente ao fato do experimento ter sido conduzido em sistema semi-intensivo e o presente estudo em sistema intensivo, que proporciona um maior ganho de peso em menor tempo para os animais e, consequentemente, valores superiores para as medidas biométricas corporais.

Araújo Filho (2007) trabalhou com cordeiros das raças Morada Nova, Santa Inês e mestiços Dorper x Santa Inês em sistema de confinamento para abate aos $30 \mathrm{~kg}$ de peso vivo. Obteve valores de 55,57 $\mathrm{cm}$ de comprimento corporal, 49,47 $\mathrm{cm}$ de comprimento de perna, 70,67 $\mathrm{cm}$ de perímetro torácico e $0,53 \mathrm{~kg} / \mathrm{cm}$ de compacidade corporal. Esses valores foram inferiores aos encontrados no presente estudo: $62,13 \mathrm{~cm}, 47,71 \mathrm{~cm}, 79,8 \mathrm{~cm}$ e 0,639 $\mathrm{kg} / \mathrm{cm}$. 
Medeiros t al. (2009) conduziram um experimento com cordeiros da raça Morada Nova, machos, castrados, em sistema de confinamento com dietas fornecidas uma vez ao dia com diferentes níveis de relação volumoso/concentrado. Os valores encontrados para largura de garupa do presente estudo foram superiores, 27,04 cm contra uma média aproximada de $14,60 \mathrm{~cm}$ do outro estudo. Para comprimento corporal encontraram $57,94 \mathrm{~cm}$, valor inferior ao de $62,13 \mathrm{~cm}$ do presente estudo e perímetro torácico de $74,94 \mathrm{~cm} \mathrm{em}$ comparação com $79,8 \mathrm{~cm}$ do presente estudo. Uma possível explicação é que a raça Morada Nova não possui aptidão para carne e os cruzamentos utilizados no presente estudo possuem raças paternas com excelente aptidão para carne. Outro fator relevante foi o fornecimento da ração uma única vez ao dia, o que diminuiu o consumo dos animais interferindo negativamente no ganho de peso.

Um estudo conduzido por Marques et al. (2008) com cordeiros da raça Santa Inês em sistema de confinamento obteve valores para comprimento corporal, largura de garupa, comprimento de perna e perímetro torácico inferiores ao encontrado no presente estudo, $55,7 \mathrm{~cm}, 15,8 \mathrm{~cm}, 41,2 \mathrm{~cm}, 70,7 \mathrm{~cm}$, respectivamente. Isso comprova o fato de que cruzamentos industriais produzem animais com melhor conformação de carcaça, maior quantidade de musculatura e melhor qualidade da carne.

Outro estudo também conduzido na Fazenda Água Limpa da Universidade de Brasília por Cardoso et al. (2013) cordeiros machos e fêmeas de três grupos genéticos (Santa Inês, Ile de France x Santa Inês e Texel x Santa Inês), confinados com dieta de 70\% de concentrado e $30 \%$ de volumoso, apresentaram valores similares para comprimento corporal, $62,25 \mathrm{~cm}$, e também para perímetro torácico, $80,12 \mathrm{~cm}$.

Osório et al. (2002) avaliaram cordeiros não castrados, de cruzamento paterno Border Leicester com ovelhas Corriedale ou ovelhas Ideal, em condições extensivas de campo nativo. Encontrou valores de comprimento corporal de 58,8 cm, comprimento de perna de 51,6 cm, $75,8 \mathrm{~cm}$ de perímetro de tórax e 0,561 de compacidade corporal. Os valores do presente estudo para as mesmas variáveis foram $62,13 \mathrm{~cm}, 47,71 \mathrm{~cm}, 79,83 \mathrm{~cm}$ e 0,639, respectivamente. $\mathrm{O}$ sistema extensivo gera animais mais tardios ao abate e com menor conformação de carcaça.

Osório et al. (2005) experimentando cordeiros Corriedale castrados e não castrados, em sistema extensivo, obteve valores de 0,522 de compacidade corporal, $56,2 \mathrm{~cm}$ de comprimento corporal, 49,7cm de comprimento de perna e $69,4 \mathrm{~cm}$ de perímetro de tórax. O 
presente estudo apresentou respectivamente valores de 0,639,62,13cm, 47,71 cm, 79,83cm para as mesmas variáveis. O sistema extensivo tem animais ao abate com menor desempenho se comparado ao sistema intensivo.

Lima (2012) avaliando cordeiros Morada Nova, inteiros e castrados, com dieta volumoso:concentrado de 50:50 em sistema de confinamento coletivo obteve valores similares para perímetro torácico $(80,71 \mathrm{~cm})$ e inferiores para as variáveis de comprimento espanhol $(56,89 \mathrm{~cm})$, comprimento neozolandês $(59,24 \mathrm{~cm})$, largura da garupa $(20,28 \mathrm{~cm})$ e largura do tórax $(25,56 \mathrm{~cm})$. Uma provável explicação é o fato de ter utilizado animais com pouca aptidão para carne e conformação de carcaça também inferior ao do presente estudo.

É possível avaliar nesse estudo que os animais provenientes dos três grupos genéticos apresentaram valores satisfatórios para as variáveis de medidas biométricas, indicando uma boa composição de carcaça. 


\section{CONCLUSÃO}

O cruzamento industrial utilizando ovelhas Santa Inês como base materna é eficaz para produção de cordeiros em sistema de confinamento, proporcionando animais precoces e com medidas biométricas desejáveis para composição de carcaça.

A utilização da raça Multimeat para produção de cordeiros em sistema de confinamento gera resultados satisfatórios e semelhantes aos apresentados por cordeiros oriundos das raças de aptidão para carne avaliadas nesse estudo. 


\section{REFERÊNCIAS BIBLIOGRÁFICAS}

AGUIAR, L. F. G. Desempenho e características da carcaça e da carne de cordeiros de diferentes grupos genéticos. 2015. 68 p. Dissertação (Mestrado) Faculdade de Agronomia e Medicina Veterinária - FAV- Universidade de Brasília (UnB), 2015.

ALMEIDA, J.C.S.; FIGUEIREDO D.M.; BOARI C.A., et al. Desempenho, medidas corporais, rendimentos de carcaça e cortes, e qualidade de carne em cordeiros alimentados com resíduos da agroindústria processadora de frutas. Semina: Ciências Agrárias, v.36, n.1, p.541-556. 2015.

ARAÚJO FILHO, J.T.; COSTA, R.G.; FRAGA, A.B. et al. Efeito de dieta e genótipo sobre medidas morfometricas e não constituintes da carcaça de cordeiros deslanados terminados em confinamento. Revista Brasileira de Saúde e Produção Animal, v.8, n.4, p.394-404, 2007.

ARAUJO FILHO, J.T.; COSTA, R.G.; FRAGA, A.B., et al. Desempenho e composição da carcaça de cordeiros deslanados terminados em confinamento com diferentes dietas. Revista Brasileira de Zootecnia, v.39, n.2, p.363-371, 2010.

CAÑEQUE, V.; SAÑUDO, C. Metodologia para el estúdio de la calidad de la canal y de la carne en rumiantes. Madrid: Instituto Nacional de Investigación y Tecnologia y Alimenticia, 2000. 255p.

CARDOSO, M.T.M.; LANDIM, A.V.; LOUVANDINI, H., et al. Performance and carcass quality in three genetic groups of sheep in Brazil. Revista Brasileira de Zootecnia, v.42, n.10, p.734-742, 2013.

CARNEIRO, P.L.S.; MALHADO, C.H.M.; SOUZA JÚNIOR, A.A.O. et al. Desenvolvimento ponderal e diversidade fenotípica entre cruzamentos de ovinos Dorper com raças locais. Pesquisa Agropecuária Brasileira, v.42, n.7, p.991-998, 2007.

CUNHA, M.G.G; CARVALHO, F.F.R.; NETO, S.G. et al. Características quantitativas de carcaça de ovinos Santa Inês confinados alimentados com rações contendo diferentes níveis de caroço de algodão integral. Revista Brasileira de Zootecnia, v.37, n.6, p.1112-1120, 2008 .

FRESCURA, R.B.M.; PIRES, C. C.; SILVA J.H.S. et al. Avaliação das proporções dos cortes da carcaça, características da carne e avaliação dos componentes do peso vivo de cordeiros. Revista Brasileira de Zootecnia, v.34, n.1, p.167-174, 2005. 
FURUSHO-GARCIA, I. F. PEREZ, J.R.O.; BONAGURIO, S., et al. Desempenho de cordeiros Santa Inês puros e cruzas Santa Inês com Texel, Ile de France e Bergamácia. Revista Brasileira de Zootecnia. v.33, n.6, p.1591-1603, 2004.

LIMA. A. G. V.O. Desempenho e características da carcaça de ovinos da raça Morada Nova de diferentes pesos, castrados e inteiros. 2012. 90 p. Dissertação (Mestrado Universidade Federal da Paraíba, 2012.

MARQUES, A.V.M.S.; COSTA, R.G.; SILVA, A.M.A. et al. Feno de flor de seda (Calotropis procera SW) em dietas de cordeiros Santa Inês: Biometria e rendimento dos componentes não-constituintes da carcaça. Revista Brasileira de Ciências Agrárias, n.1, v.3, p.85-89, 2008

MORENO, G.M.B.; SILVA SOBRINHO, A.G.; ROSSI, R .C. et al. Desempenho e rendimentos de carcaça de cordeiros Ile de France desmamados com diferentes idades. Revista Brasileira de Saúde e Produção Animal, v.11, p.1105-1116, 2010.

NATIONAL RESEARCH COUNCIL - NRC. Nutrient Requeriments of Small Ruminants. National Academy Press Washington: National Academy. Press, 2007. 362p.

OSÓRIO, J.C.S.; OLIVEIRA, N.M.; OSÓRIO, M.T.M. et al. Produção de carne em cordeiros cruza Border Leicester com ovelhas Corriedale e Ideal. Revista Brasileira de Zootecnia, v.31, n.3, p.1469-1480, 2002 (suplemento).

OSÓRIO, J.C.S.; OSÓRIO, M.T.M.; MENDONÇA, G. et al. Morfologia e características produtivas e comerciais em cordeiros corriedale castrados e não castrados. Revista Brasileira Agrociência, v.11, n.2, p.211-214, 2005.

PINHEIRO, R.S.B., JORGE, A.M. Medidas biométricas obtidas in vivo e na carcaça de ovelhas de descarte em diferentes estágios fisiológicos. Revista Brasileira de Zootecnia v.39, n.2, p.440-445, 2010.

PINHEIRO, R.S.B.; SILVA SOBRINHO, A.G.; MARQUES, C.A.T. et al. Biometría in vivo e da carcaça de cordeiros confinados. Archivos de Zootecnia, v.56 n.216, p.955-958. 2007.

PIRES, C.C.; SILVA, L.F.; SCHLICK, F.E. et al. Cria e terminação de cordeiros confinados. Ciência Rural, v.30, n.5, p.875-880, 2000.

QUEIROZ, M.A.A.; SUSIN, I.; PIRES, A.V. et al. Desempenho de cordeiros e estimativa da digestibilidade do amido de dietas com diferentes fontes protéicas. Pesquisa Agropecuária Brasileira, v.43, n.9, p.1193-1200, 2008.

SAÑUDO, C.; SIERRA, L.L.; OLLETA, J.L. et al. Influence of weaning on carcass quality, fatty acid composition and meat quality in intense lamb production systems. Journal Science, v.66, p.175-187, 1998.

SAS. Institute Inc. Introductory guide for personal computers. Version 9.2 2009. CDROM.

SILVA SOBRINHO, A. G. Aspectos quantitativos e qualitativos da produção de carne ovina. In: SOCIEDADE BRASILEIRA DE ZOOTECNIA. A produção animal na visão dos brasileiros. Piracicaba: FEALQ, 2001. p.425-446. 
SILVA, D.J.; QUEIROZ, A.C. Análise de Alimentos: métodos químicos e biológicos. Viçosa: UFV, Imprensa Universitária, 2002. 235p.

SOUSA, W. H. Desempenho e característica de carcaça de cordeiros terminados em confinamento com diferentes condições corporais. Revista Brasileira de Saúde e Produção Animal, v.9, n.4, p.795-803, 2008.

VIEIRA, T.R.L.; CUNHA, M.G.G.; GARRUTTI, D.S. et al. Características físicas e sensoriais da carne de cordeiros Santa Inês terminados em dietas com diferentes níveis de caroço de algodão integral. Ciência e Tecnologia Alimentos., Campinas, 30(2): 372-377, 2010 .

YÁÑEZ, E.A. Desenvolvimento relativo dos tecidos e características da carcaça de cabritos Saanen, com diferentes pesos e níveis nutricionais. 2002. 85p. Tese (Doutorado em Zootecnia). Faculdade de Ciências Agrárias e Veterinária, Universidade Estadual Paulista, Jaboticabal, 2002.

YÁÑEZ, E.A.; RESENDE, K.T; FERREIRA, A.C.D. et al. Restrição alimentar em caprinos: rendimento, cortes comerciais e composição da carcaça. Revista Brasileira de Zootecnia, Viçosa, v.35, n.5, p.2093-2100, 2006.

ZEOULA, N.M.B.L. Influência da alimentação nas características quantitativas da carcaça e qualitativas da carne de cordeiros Morada Nova. Jaboticabal: Universidade de São Paulo. 2002

ZUNDT, M.; MACEDO, F.A.F.; MARTINS, E.N.; MEXIA, A.A.; YAMAMOTO, S.M. Desempenho de Cordeiros Alimentados com Diferentes Níveis Protéicos. Revista Brasileira de Zootecnia, v.31, n.3, p.1307-1314, 2002. 